\title{
Basic values of Russian and foreign students (comparative aspect)
}

\author{
Valores básicos de estudantes russos e estrangeiros (aspecto \\ comparativo)
}

\section{Valores básicos de estudiantes rusos y extranjeros (aspecto comparativo)}

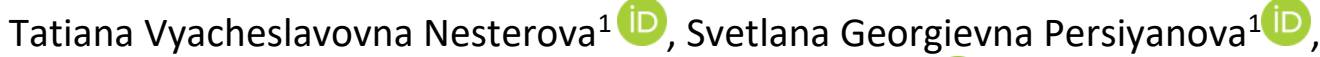 \\ Bagaudin Ibragimovich Karadzhev ${ }^{1}$ iD
}

${ }^{1}$ Pushkin State Russian Language Institute, Moscow, Russia.

Corresponding author:

Tatiana Vyacheslavovna Nesterova

Email:TVNesterova@pushkin.institute

How to cite: Nesterova, T. V., Persiyanova, S. G., \& Karadzhev, B. I. (2021). Basic values of Russian and foreign students (comparative aspect). Revista Tempos e Espaços em Educação, 14(33), e15263.

http://dx.doi.org/10.20952/revtee.v14i33.15263

\section{ABSTRACT}

The article deals with the comparison of the basic values of modern students (Russian and foreign). The authors examine and compare basic values held by modern students (Russian and foreign). The study is based on the typology of basic values of Russians (research project "Tomskaya initsiativa", 2001) and the list of values from the S. Schwartz Value Survey. The respondents are asked to choose 10 key values out of 40 basic values and assess them using the S. Schwartz scale. The surveys performed by the authors at the Pushkin State Russian Language Institute and Moscow Automobile and Road Construction State Technical University are used as the materials for the study.

Keywords: Values. Basic values. Value orientations. Axiological worldview. Students.

\section{RESUMO}

O artigo trata da comparação dos valores básicos dos estudantes modernos (russos e estrangeiros). Os autores examinam e comparam os valores básicos mantidos por estudantes modernos (russos e estrangeiros). O estudo é baseado na tipologia de valores básicos dos russos (projeto de pesquisa "Tomskaya initsiativa", 2001) e na lista de valores do S. Schwartz Value Survey. Os entrevistados são convidados a escolher 10 valores-chave de 40 valores básicos e avaliá-los usando a escala de $S$. Schwartz. As pesquisas realizadas pelos autores do Pushkin State Russian Language Institute e da Moscow Automobile and Road Construction State Technical University são usadas como materiais para o estudo.

Palavras-chave: Valores. Valores básicos. Orientações de valor. Visão de mundo axiológica. Alunos. 


\section{RESUMEN}

El artículo trata de la comparación de los valores básicos de los estudiantes modernos (rusos y extranjeros). Los autores examinan y comparan los valores básicos de los estudiantes modernos (rusos y extranjeros). El estudio se basa en la tipología de valores básicos de los rusos (proyecto de investigación "Tomskaya initsiativa", 2001) y la lista de valores de la Encuesta de valores de S. Schwartz. Se pide a los encuestados que elijan 10 valores clave de 40 valores básicos y los evalúen utilizando la escala de S. Schwartz. Las encuestas realizadas por los autores en el Instituto Estatal de Lengua Ruso Pushkin y la Universidad Técnica Estatal de Construcción de Automóviles y Carreteras de Moscú se utilizan como materiales para el estudio.

Palabras clave: Valores. Valores básicos. Orientaciones de valor. Cosmovisión axiológica. Estudiantes.

\section{INTRODUCTION}

At the heart of any culture is its inherent system of values that are every person's ideological attitudes and guiding principles. The subject of this article is the comparison of the basic values of modern students (Russian and foreign). According to N.I. Lapin and L.A. Belyaeva (1996), basic values are formed at the stage of primary socialization by the age of 18-20 and after that are quite stable, although these values may undergo some changes during crisis periods in the person's life and their social environment. However, in this case, we mean a change not in the composition of values but their very structure, a hierarchical arrangement in the consciousness of an individual, a group or society as a whole: some values prove more significant, others, on the contrary, less significant. The relevance of studying modern students' values is confirmed by many factors. First, in any historical period, youth acts as a driving force for the development of society and the same can be said about modern youth. Second, the values of student youth reflect the economic, political, spiritual and social spheres of modern society. Third, student youth are inherently dynamic in terms of their susceptibility to the influence of political and economic factors. Fourth, youth is not only a kind of indicator of the ongoing changes but also forms the basis of the future. Further life of society, its development in cultural and material terms completely depend on the preferences of today's youth, therefore the question of the values of modern student youth is becoming increasingly important (Tsennostnye orientatsii rossiiskoi molodezhi i realizatsiya gosudarstvennoi molodezhnoi politiki: rezultaty issledovaniya, n.d.).

Understanding the values of human existence is one of the most important tasks of modern scientific knowledge. The analysis of value orientations is of paramount importance in such sciences as philosophy (Kratkaya filosofskaya entsiklopediya, 1994; Abushenko, 2002; Prokhorov, 2002) sociology (Parsons, 1972; Thamas, 1976; Durkheim, 1995), psychology (Schwartz \& Bilsky, 1958; Rokeach, 1973; Schwartz \& Bilsky, 1987), cultural linguistics (Karasik, 2002; 2015; 2018) and axiological linguistics (Karasik, 2014; 2015; 2019).

Modern scholars interpret the concept of "value" in different ways. For example, V.L. Abushenko defines values as "the semantic foundations of human existence that setting the orientation and motivation of human life" (Abushenko, 2002, p. 21). V.I. Karasik considers values "the most fundamental characteristics of culture, the highest guidelines of behavior" (Karasik, 2002, p.166). A.A. Ivin writes, "values are objects of some interest, desire, aspiration, etc., or /.../ objects that are significant for a person or a group of people. In a more general case, any object of any interest is considered a value. /.../ This is not a property but a relationship between thought and reality" (Ivin, 2019, p. 67).

Numerous works are dedicated to defining basic values and their classifications: (Zemrakh, 2005; Magun \& Rudnev, 2008; Rudnev, 2009). Basic values express the most important ideals, goals and meanings of people's lives. These are "the most stable universal human values that are relevant for both traditional and modern society" (Ishankulova, 2011, p. 32). V.S. Magun understands basic 
values as "those final, goal values of a person, based on which the whole set of instrumental (operational, current) values are formed that guide the person's life" (Magun, 2002, p. 24). According to S. Schwartz, basic values are those that represent the universal needs of human existence (Schwartz, 1992). "Although they are reflected in all cultures, in each of them they are filled out in different ways, revealing the unique features of each specific culture" (Sinyachkin, 2011, p.44). V.V. Kryukov (Kryukov, 2003) believes that the basic values of a society depend on the goals and problems that society solves in a certain historical period and reflect the needs of this society.

The description of the value orientations of modern youth and their dynamic patterns are presented in several studies: (Tseplyaev, 2000; Zemrakh, 2005; Mitryushin, 2008). Here we can highlight the works devoted to the consideration of the priority values of modern youth in Russia in a certain period (Vagin, 2015; Rozenova, 2006), methods of linguistic representation of value orientations in the linguistic worldview of youth (Nesterova \& Nagorneva, 2016; Votintseva, 2018), the relationship between the value orientations of Russian youth and the state youth policy (Tsennostnye orientatsii rossiiskoi molodezhi i realizatsiya gosudarstvennoi molodezhnoi politiki: rezultaty issledovaniya, n.d.). A promising area today is the comparative study of students' values (Svetonosova, 2006; Rudnev, 2009; Glazkova, 2009). In this article, we examine the basic values of modern students (Russian and foreign) from this point of view.

The material for the analysis was the data obtained during a survey conducted in April-May 2020. The respondents included freshmen from the Philological Department at the Pushkin State Russian Language Institute (Russians and foreigners), foreign students of the Department of Teaching Russian as a Foreign Language at the Pushkin State Russian Language Institute and sophomores from the Faculty of Road Building at the Moscow Automobile and Road Construction State Technical University (MADI) (young men and women from 17 to 22 years old). The survey was taken by 100 Russian students and 75 foreign students ( 30 Vietnamese and 45 Chinese students).

\section{METHODOLOGY}

We used the following research methods in the study: descriptive-analytical method, definitional analysis method, methods of collecting empirical data, survey method in the form of questionnaires of Russian and foreign students, method of quantitative-statistical analysis and comparative-comparative analysis.

\section{RESULTS AND DISCUSSION}

There are various classifications of basic values (World Values Survey 1981-2014 Longitudinal Aggregate, n.d.). We conducted the study based on the typology of basic values of Russians (research project "Tomskaya initsiativa", 2001 (Karasik, 2019)), as well as the list of values from the S. Schwartz Value Survey (Tsennostnyi oprosnik Shvartsa, n.d.).

All students were asked to assess 40 values on the $S$. Schwartz scale: 7 - supremely important value as a guiding principle in life (usually there is one or two); 6 - very important; 5 - quite important; 4 - important; 3 - not very important; 2 - of little importance; 1 - not important; 0 completely indifferent; -1 - opposite to your values. These 40 values included: 1) love, 2) freedom, 3) friendship, 4) family, 5) family safety, 6) life, 7) inner harmony, 8) good, 9) self-respect, 10) health, 11) life full of experiences, 12 ) world peace, 13) creativity, 14) education, 15) spiritual life, 16) selfdiscipline, 17) pleasure, 18) professionalism, 19) personal safety, 20) marriage for love, 21) politeness, 22) respect for the opinions of others, 23) equality, 24) the meaning of life, 25) respect for parents, 26) work, 27) career, 27) national security, 29) legality, 30) homeland, 31) respect for elders, 32) stability, 33) wealth, 34) duty, 35) patriotism, 36) respect for tradition, 37) sacrifice, 38) popularity, 39) power, 40) religion. 
As a result of the survey, we obtained the following results (the results are presented in diagrams; the numbers indicate the number of people who chose this value):

Figure 1. Distribution of answers by indicator (7 - supremely important values)

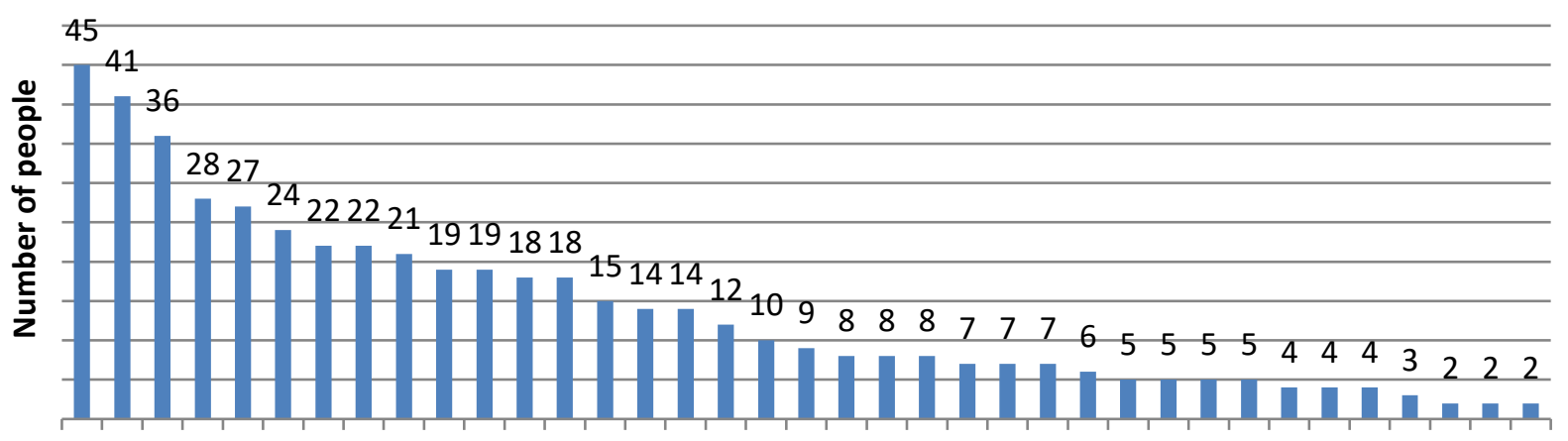

$122 \quad 3 \quad 4 \quad 5 \quad 6 \quad 7 \quad 8 \quad 910111213141516171819202122232425262728293031323334353637$

Values

1 - love; 2 - freedom; 3 - family; 4 - life; 5 - inner harmony; 6 - friendship; 7 - world peace; 8 - marriage for love; 9 family safety; 10 - good; 11 - a life full of experiences; 12 - self-respect; 13 - the meaning of life; 14 - health; 15 creativity; 16 - spiritual life; 17 - personal safety; 18 - pleasure; 19 - respect for parents; 20 - education; 21 - selfdiscipline; 22 -work; 23 - professionalism; 24 - politeness; 25 - equality; 26 -national security; 27 -career; 28 - respect for elders; 29 - wealth; 30 - duty; 31 - respect for the opinions of others; 32 - homeland; 33 - stability; 34 - legality; 35 - patriotism; 36 - power; 37 - religion.

Figure 2. Distribution of answers by indicator (6 - very important values)

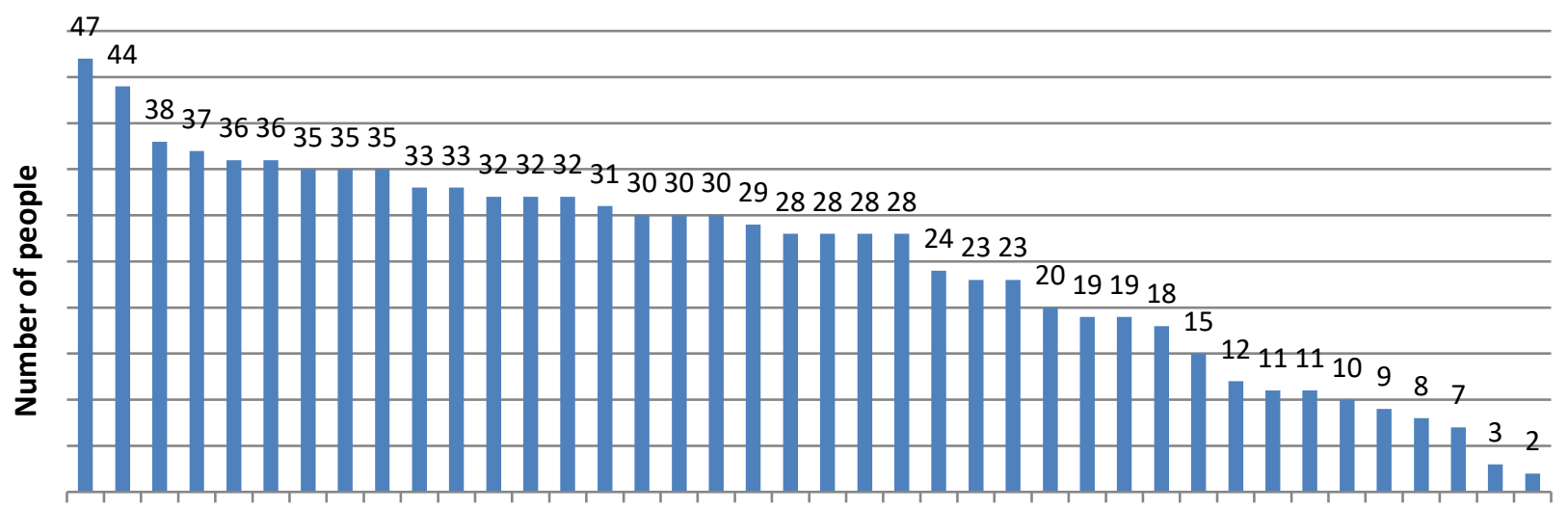

$123 \quad 4 \quad 5 \quad 6789910111213141516171819202122232425262728293031323334353637383940$

Values

1 -friendship; 2 - family safety; 3 - health; 4 - life; 5 -love; 6 - equality; 7 -inner harmony; 8 - good; 9 - self-respect; 10 - education; 11 - spiritual life; 12 - a life full of experiences; 13 - world peace; 14 - marriage for love; 15 - selfdiscipline; 16 - freedom; 17 - creativity; 18 - professionalism; 19 - personal safety; 20 - family; 21 - pleasure; 22 politeness; 23 - respect for the opinions of others; 24 - respect for parents; 25 - career; 26 - legality; 27 - work; 28 the meaning of life; 29 - national security; 30 - homeland; 31 - respect for elders; 32 - stability; 33 - patriotism; 34 respect for traditions; 35 - duty; 36 - wealth; 37 - sacrifice; 38 - religion; 39 - popularity; 40 - power. 
Figure 3. Distribution of answers by indicator (5 - quite important values)

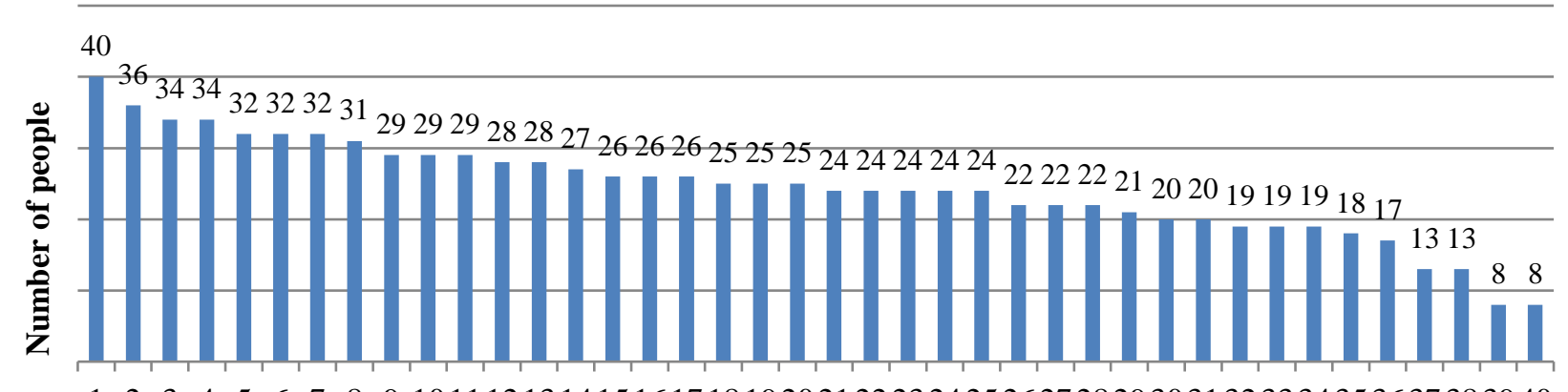

1233456778910111213141516171819202122232425262728293031323334353637383940

Values

1 - respect for the opinions of others; 2 - professionalism; 3 - education; 4 - respect for parents; 5 -creativity; 6 - selfdiscipline; 7 - pleasure; 8 - politeness; 9 - self-respect; 10 - a life full of experiences; 11 - work; 12 - spiritual life; 13 national security; 14 - family safety; 15 - health; 16 - world peace; 17 - personal safety; 18 - good; 19 - equality; 20 career; 21 - freedom; 22 - marriage for love; 23 - the meaning of life; 24 - stability; 25 - duty; 26 - respect for elders; 27 - wealth; 28 - sacrifice; 29 - family; 30 - life; 31 - legality; 32 - inner harmony; 33 - homeland; 34 - patriotism; 35 - friendship; 36 - respect for traditions; 37 - love; 38 - popularity; 39 - power; 40 - religion.

Figure 4. Distribution of answers by indicator (4 - important values)

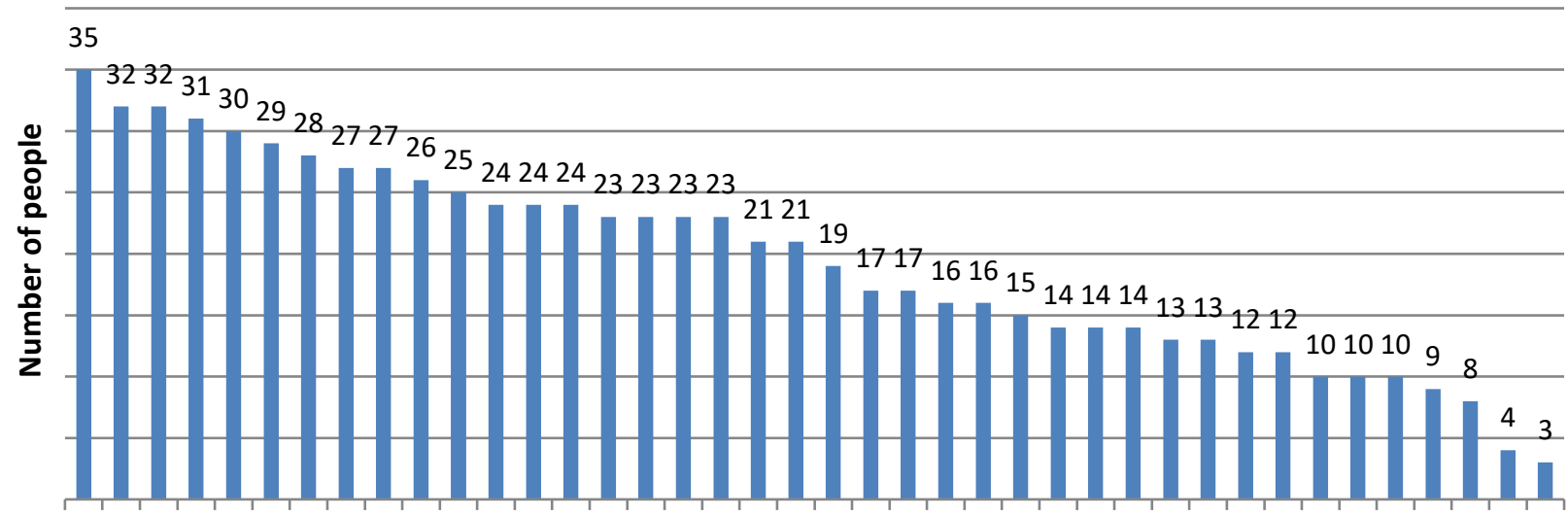

$123 \quad 456678910111213141516171819202122232425262728293031323334353637383940$

Values

1 - stability; 2 - homeland; 3 - wealth; 4 - work; 5 - duty; 6 - legality; 7 - career; 8 - personal safety; 9 - politeness; 10 - respect for elders; 11 - pleasure; 12 - the meaning of life; 13 - patriotism; 14 - respect for traditions; 15 - education; 16 - self-discipline; 17 - professionalism; 18 - national security; 19 - respect for the opinions of others; 20 - sacrifice; 21 - respect for parents; 22 - health; 23 - spiritual life; 24 - good; 25 - equality; 26 - creativity; 27 - self-respect; 28 marriage for love; 29 - power; 30 - inner harmony; 31 - popularity; 32 - family; 33 - a life full of experiences; 34 - life; 35 - world peace; 36 - religion; 37 - friendship; 38 - family safety; 39 - freedom; 40 - love. 
Figure 5. Distribution of answers by indicator (3 - not very important values)

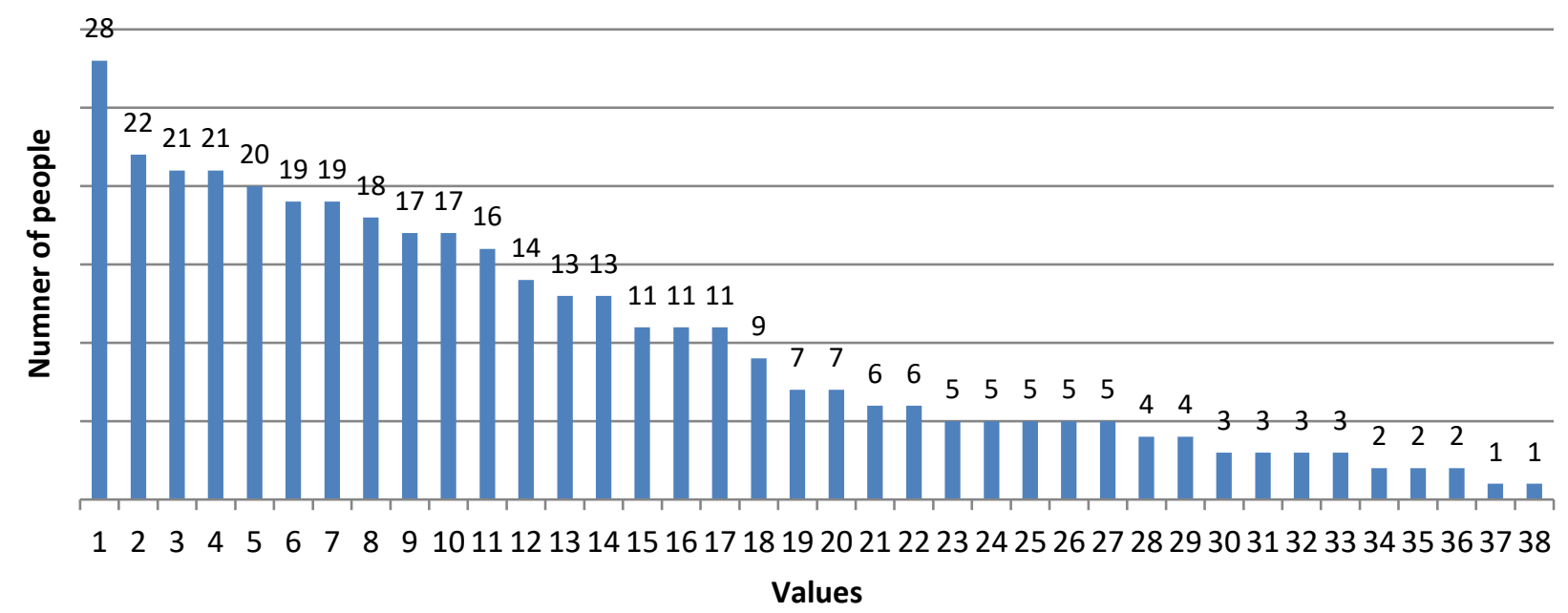

1 - popularity; 2 - respect for traditions; 3 - wealth; 4 - patriotism; 5 - power; 6 - respect for elders; 7 - sacrifice; 8 duty; 9 - national security; 10 - homeland; 11 - legality; 12 - career; 13 - stability; 14 - religion; 15 - equality; 16 - the meaning of life; 17 - respect for parents; 18 - work; 19 - creativity; 20 - politeness; 21 - a life full of experiences; 22 world peace; 23 - inner harmony; 24 - self-discipline; 25 - pleasure; 26 - personal safety; 27 - marriage for love; 28 self-respect; 29 - professionalism; 30 - love; 31 - good; 32 - health; 33 - respect for the opinions of others; 34 friendship; 35 - family; 36 - spiritual life; 37 - life; 38 - education.

Figure 6. Distribution of answers by indicator (2 - values of little importance)

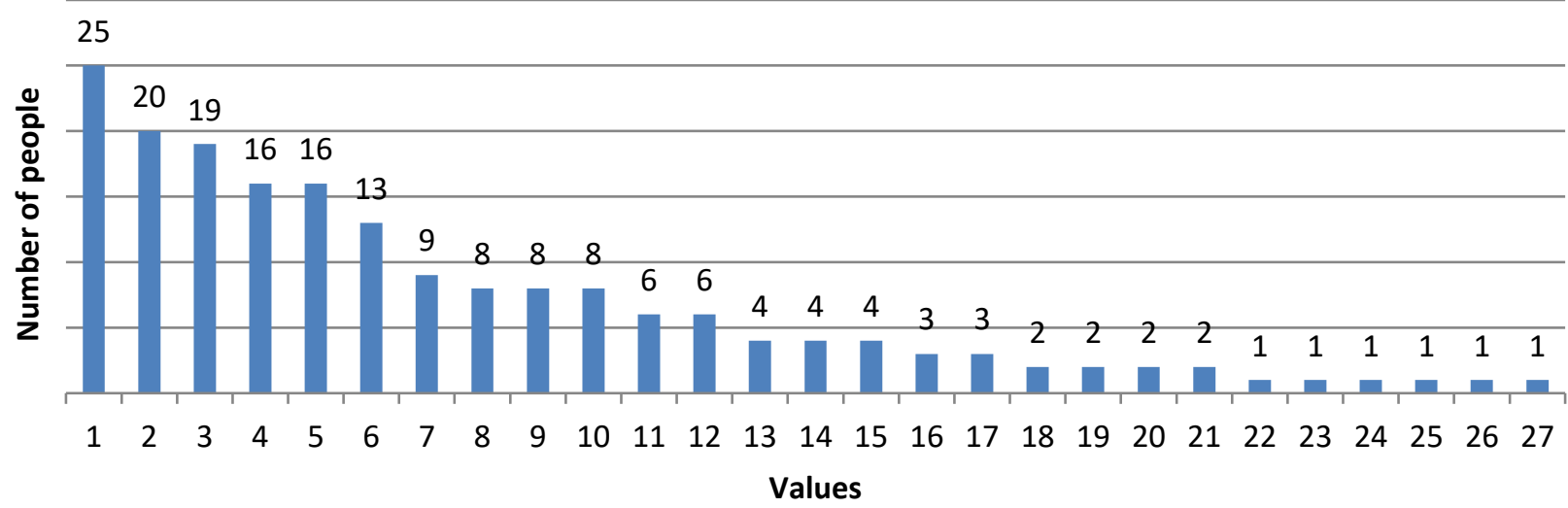

1 - power; 2 - religion; 3 - sacrifice; 4 - respect for traditions; 5 - popularity; 6 - patriotism; 7 - homeland; 8 - respect for elders; 9 - wealth; 10 - duty; 11 - legality; 12 - stability; 13 - spiritual life; 14 - career; 15 - national security; 16 equality; 17 - work; 18 - a life full of experiences; 19 - creativity; 20 - respect for the opinions of others; 21 - respect for parents; 22 -inner harmony; 23 -good; 24 - health; 25 - education; 26 - self-discipline; 27 - the meaning of life. 
Figure 7. Distribution of answers by indicator (1 - not important values)

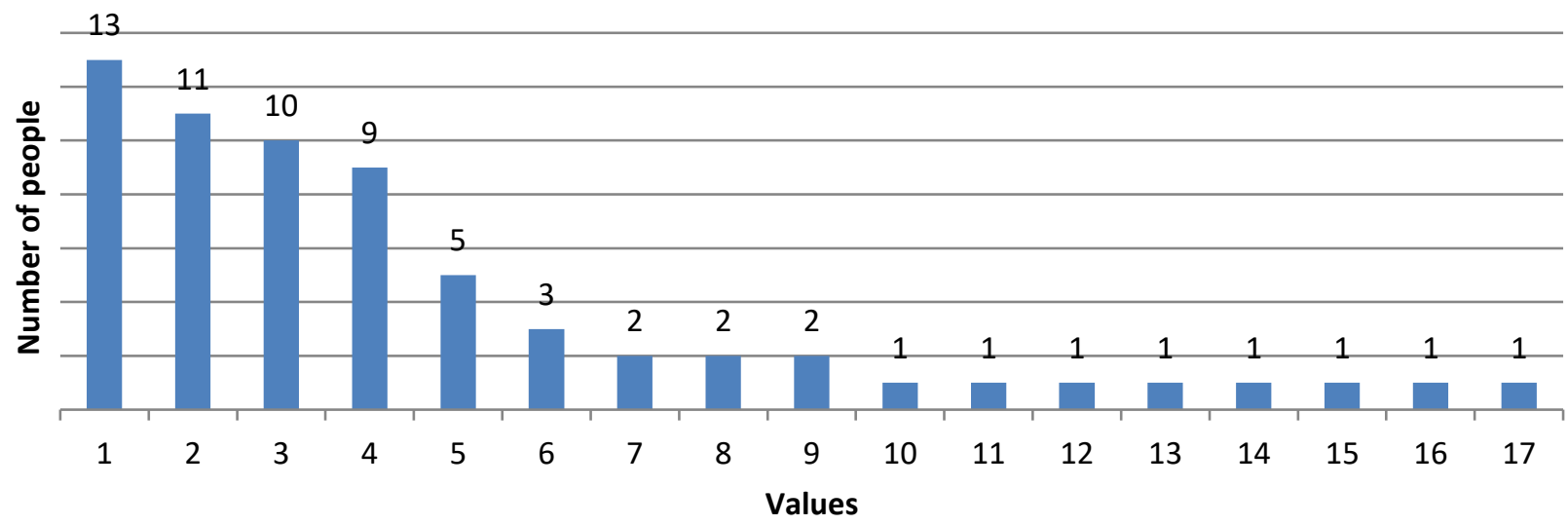

1 - religion; 2 - popularity; 3 - power; 4 - respect for traditions; 5 - sacrifice; 6 - patriotism; 7 - national security; 8 respect for elders; 9 - stability; 10 - world peace; 11 - personal safety; 12 - respect for the opinions of others; 13 equality; 14 - career; 15 - legality; 16 - wealth; 17 - duty.

Figure 8. Distribution of answers by indicator (0 - completely indifferent values)

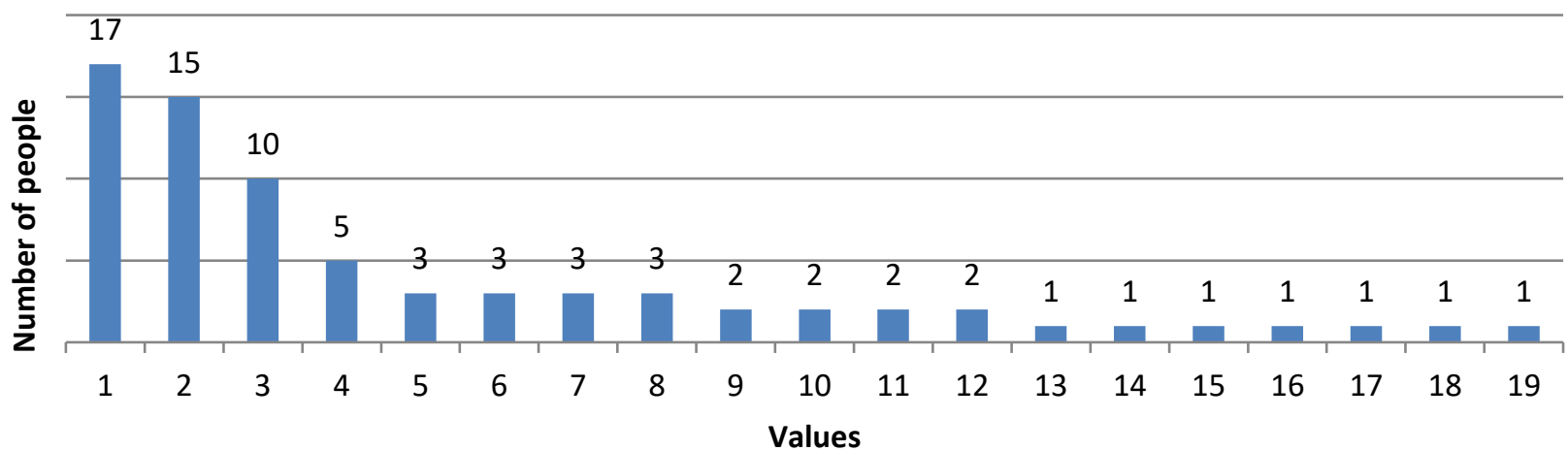

1 - religion; 2 - popularity; 3 - power; 4 - patriotism; 5 - world peace; 6 - the meaning of life; 7 - respect for elders; 8 - stability; 9 - spiritual life; 10 - marriage for love; 11 - legality; 12 - duty; 13 - family; 14 - respect for the opinions of others; 15 - equality; 16 - respect for parents; 17 - national security; 18 - respect for traditions; 19 - sacrifice.

Thus, Russian students' top 10 leading (basic) values that were rated six or seven include:

Table 1. Russian students' top 10 leading (basic) values

\begin{tabular}{ccccc}
\hline № & Value & Rated 7 & Rated 6 & Number of people \\
\hline 1 & Love & 45 & 36 & 81 \\
2 & Freedom & 41 & 30 & 71 \\
3 & Friendship & 24 & 47 & 71 \\
4 & Family safety & 21 & 44 & 65 \\
5 & Life & 28 & 37 & 65 \\
6 & Family & 36 & 28 & 64 \\
7 & Inner harmony & 27 & 35 & 62 \\
8 & Good & 19 & 35 & 54 \\
9 & Marriage for love & 22 & 32 & 54 \\
10 & World peace & 22 & 32 & 54 \\
\hline
\end{tabular}


It is worth noting that students understand the essence of these values in different ways. Here are example interpretations (unedited for spelling or grammar):

1. Love: a feeling of incredible happiness and tranquility. As if the whole world is contained in the person you love; an all-consuming feeling that drives humanity, love for the world; a zone of security and complete trust; care; excellent relationship with the person; a never-fading outburst of emotions; the ability to sacrifice your life for the sake of another, placing the other's life and interests above your own; spiritual closeness + bodily attraction; feeling of cordial kinship, striving for a common goal, affection; a chemical reaction, romanticization; the will to live, interest in others, care for them, sincerity and happiness; life without hatred, anger, striving to help others, make them happy; "unity of souls", a feeling of deep affection for another person; a strong feeling that arises between people, as a rule, of the opposite sex; love for everything: family, friends, the world; caring for people, sacrifice, closeness; family, etc.

2. Freedom: the ability to do what you want, not to depend on others; freedom of choice and action, self-expression and speech; freedom from social pressure; independent decision-making in life; no attachments; the awareness that only you are responsible for your choices and actions; the ability to always make decisions independently, to act as I see fit (within the law); the right to make choices; the ability to distribute your time as you need and not as dictated by responsibilities; the ability to do what you really like, not to be shackled by poverty, debt; freedom of choice of specialty, freedom of self-expression; to be able to be yourself: choose what to do in life, whom to love, in which direction to develop, where to live; achieving inner harmony with oneself; the ability to do what you want (within reason, of course); not restricting the rights of people because of their gender / race / age / orientation, as well as the ability to express their political position; the ability to choose your own path in life, make decisions and follow them, etc.

3. Friendship: mutual assistance, reciprocity, support at any time; to have close people who will always support and help; strong emotional connection with some people; fun; mutual support and love, willingness to sacrifice one's own interests for the sake of another; understanding, absolute trust, mutual assistance; the presence of people in your life who accept and love you; close, trusting relationship with a certain circle of people; the type of relationship in which each participant can count on the help and support of the other; relationships between people based on trust, mutual understanding, common interests; mutual assistance, sacrifice; trust, the ability to rely on a person, etc.

4. Family safety: all close people are safe, everything is fine with them; the knowledge that dear people are not in danger; the protection of family from external threats; the protection of life and health of close relatives; psychologically comfortable environment in the family; it is freedom, the absence of fear for the safety of the relatives' lives; your family has a roof over their heads, parents live in prosperity; the protection of life and health of one's family members (including legal); the safety of the home in which you live; absence of military conflicts in the country, family health; peace and harmony in the family; peaceful family life in health and calm; financial and physical security, stability, etc.

5. Life: the very fact of my existence; great luck; the most valuable thing a person has; human existence on Earth, the period of human life; the path from birth to death; being grateful for everything you have while having a goal and going towards it; the desire to learn something new, to be in harmony with oneself and the world, not to stand still, to enjoy the little things; the ability to breathe, move, think - do whatever you want; the inalienable right of every person to exist; the ability to enjoy oneself; something that no one should take away; for me life is a gift, it is something that I have no right to waste; not empty or superficial existence; a road; lack of death; the universe, nature, everything that exists around us, etc.

6. Family: the closest and dearest people; parents and a soulmate; family and friends who are ready to help and support at any second; people united by blood ties and a special spiritual world; 
a group of people in a relationship; the people you live with; people connected by blood ties; people who truly love each other; a partner and children; the most precious thing in life; union of two loving people; a place where they will understand and support; a place where you are always loved and expected; protection; support, etc.

7. Inner harmony: to be in harmony with yourself, love your soul and body; to be in tune with your feelings and thoughts; there is no departure from moral principles; feeling of inner satisfaction with your life and decisions; a state of balance, living in harmony with oneself and one's principles; to live in peace with everyone; lack of internal contradictions, wars, conflicts that bring emotional discomfort; feeling of happiness and prosperity in all spheres of life (family, career, hobby); understanding yourself, your feelings and needs; peace of mind and balance; feeling of inner peace, lack of anxiety; health; lack of stress; true freedom; humility; life according to conscience; difficult to achieve, etc.

8. Good: too abstract concept, but very important; selfless support; actions for the benefit of others, thinking about others as much as about yourself; life without wars and epidemics; when all people live in peace; everything that is useful to people and society contributes to the prosperity and a better life; ability to empathize; compassion, helping others; what the world is based on; selfsacrifice in its various manifestations for the sake of another; the ability to help others and support them in difficult times; showing mercy, willingness to always come to the aid of someone in need; love for humanity and each person individually; respect for others, compassion, benevolence; Christianity; rare occurrence, etc.

9. Marriage for love: a marriage between people who love and respect each other; the only reason to get married; I do not accept any other marriages; a marriage between people who truly love each other; a voluntary union of two loving people as a family; creating a family with a person you love; long happy life of a married couple in mutual understanding and respect; you can marry money, but there will be no happiness; something idealized; dream, etc.

10. World peace: No war; a state of absolute calm, without wars and epidemics; absence of wars and world conflicts; a world without war, mutual respect of states and their peoples for each other; no war, terrorist attacks, discrimination and any other form of violence and infringement of human rights; absence of war, mutual understanding between people, tolerance; kindness, love and harmony; a world without discrimination against anyone on any grounds; victory over nationalism, racism, etc.; reducing the importance of money; a state without war and poverty; utopia, but I would very much like to abandon senseless wars; utopia, but I would like to do everything possible for it, etc.

In the comments of Russian students, both a narrow and a broad understanding of each value are presented. Moreover, there is an overlap with values that students rated as 3 (not very important), 2 (of little importance), 1 (not important), 0 (completely indifferent). Thus, for example, "sacrifice" (2 - not very important) is a component in "love" and "friendship" and "legality" is part of "freedom and safety of the family." We identified many contradictions in the assessments of students: the respondents want freedom, independence from others, but at the same time want to be in harmony with the world; see freedom in the absence of attachment but understand love as caring for other people, etc. "Popularity" was among the values that students rated from 3 to 0 but, at the same time, many of them strive to become popular in the Internet community. The leading position is still retained by "love" (Rozenova, 2006; Glazkova, 2009; Vagin, 2015), which is understood in different ways by students (see comments above). "Family safety" was in the top five (with the family in 6th place, chosen by 64 students). Many students associate this value not only with the absence of an external threat but also with the security of the life and health of their loved ones. It seems that the current situation with the COVID-19 pandemic also influenced the choice of this value. Unfortunately, values such as "homeland", "patriotism", "respect for traditions", "respect 
for elders" and "respect for parents" received scores from 3 to 0 from some students (isolated cases).

\section{Foreign students' basic values}

\section{Chinese students' basic values}

The survey was taken by 25 young women and 20 young men aged $19-22$. The results of the survey are presented in the diagrams.

Figure 9. Distribution of answers by indicator (7 - supremely important values)

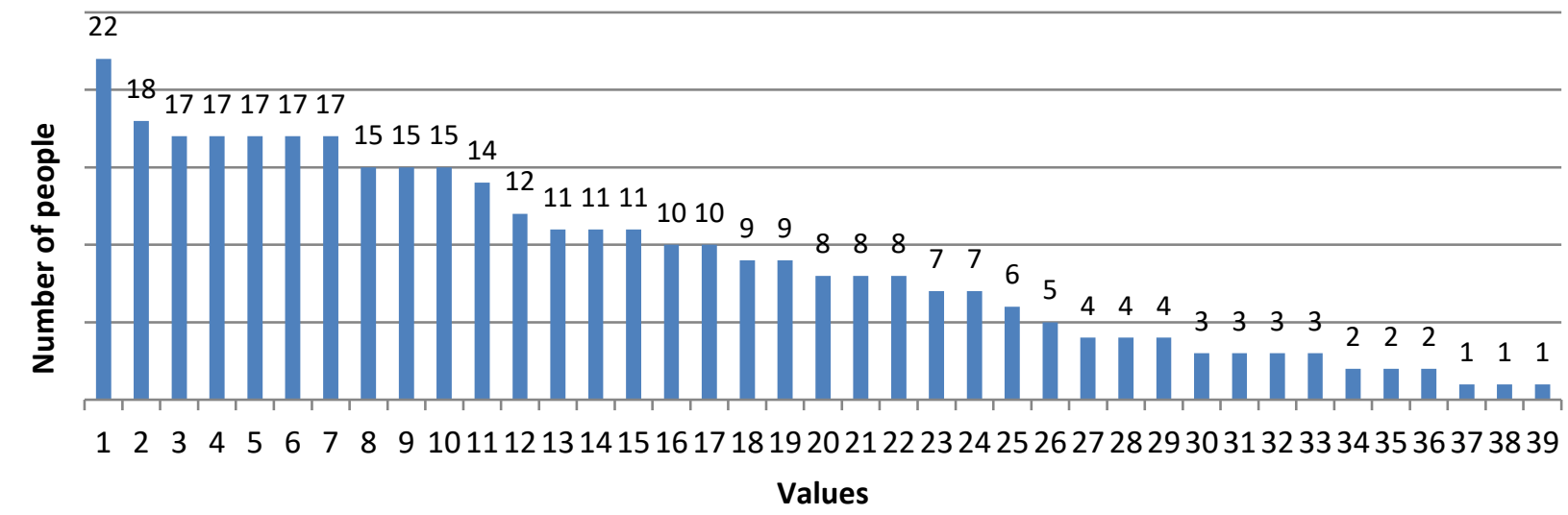

1 - health; 2 - life; 3 - homeland; 4 - good; 5 - national security; 6 - family; 7 - family safety; 8 - freedom; 9 - world peace; 10 - love; 11 - patriotism; 12 - self-respect; 13 - spiritual life; 14 - respect for parents; 15 - personal safety; 16 - inner harmony; 17 - friendship; 18 - education; 19 - marriage for love; 20 - pleasure; 21 - the meaning of life; 22 legality; 23 - equality; 24 - respect for elders; 25 - self-discipline; 26 - career; 27 - a life full of experiences; 28 - respect for the opinions of others; 29 - professionalism; 30 - wealth; 31 - respect for traditions; 32 - power; 33 - creativity; 34 - work; 35 - stability; 36 - duty; 37 - politeness; 38 - popularity; 39 - religion.

Figure 10. Distribution of answers by indicator (6 - very important values)

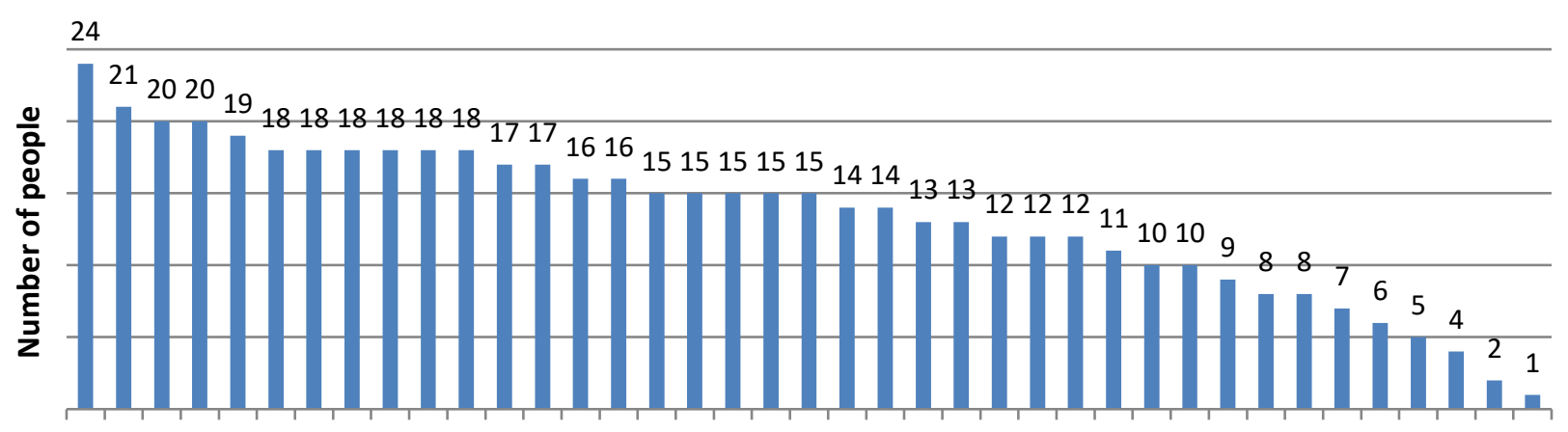

$123 \quad 4 \quad 5 \quad 6 \quad 7 \quad 89101112131415161718192021222324252627282930313233343536373839$

Values

1-politeness; 2 -legality; 3 - respect for the opinions of others; 4 - professionalism; 5 - national security; 6 - homeland; 7 - education; 8 - work; 9 - patriotism; 10 - respect for parents; 11 - personal safety; 12 - equality; 13 - family; 14 spiritual life; 15 - pleasure; 16 - freedom; 17 - a life full of experiences; 18 - inner harmony; 19 - self-discipline; 20 friendship; 21 - health; 22 - the meaning of life; 23 - love; 24 - life; 25 - self-respect; 26 - career; 27 - respect for elders; 28 - creativity; 29 - world peace; 30 - duty; 31 - family safety; 32 - wealth; 33 - good; 34 - stability; 35 - respect for traditions; 36 - marriage for love; 37 - sacrifice; 38 - religion; 39 - power. 
Figure 11. Distribution of answers by indicator (5 - quite important values)

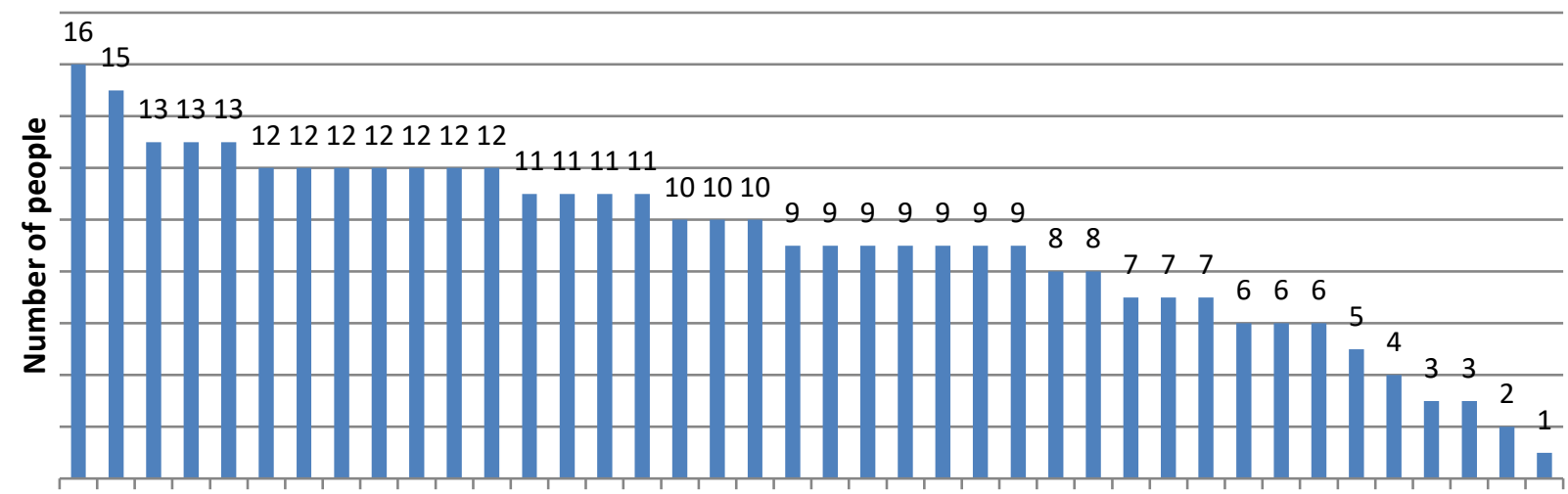

122344566789910111213141516171819202122232425262728293031323334353637383940

Values

1 - creation; 2 - respect for traditions; 3 - self-discipline; 4 - career; 5 - duty; 6 - spiritual life; 7 - a life full of experiences; 8 - politeness; 9 - inner harmony; 10 - education; 11 - work; 12 - respect for elders; 13 - freedom; 14 professionalism; 15 - the meaning of life; 16 - stability; 17 - good; 18 - respect for the opinions of others; 19 - power; 20 - wealth; 21 - sacrifice; 22 - self-respect; 23 - world peace; 24 - friendship; 25 - life; 26 - respect for parents; 27 equality; 28 - popularity; 29 - pleasure; 30 - patriotism; 31 - personal safety; 32 - legality; 33 - marriage for love; 34 religion; 35 - family safety; 36 - family; 37 - love; 38 - health; 39 - homeland; 40 - national security.

Figure 12. Distribution of answers by indicator (4 - important values)

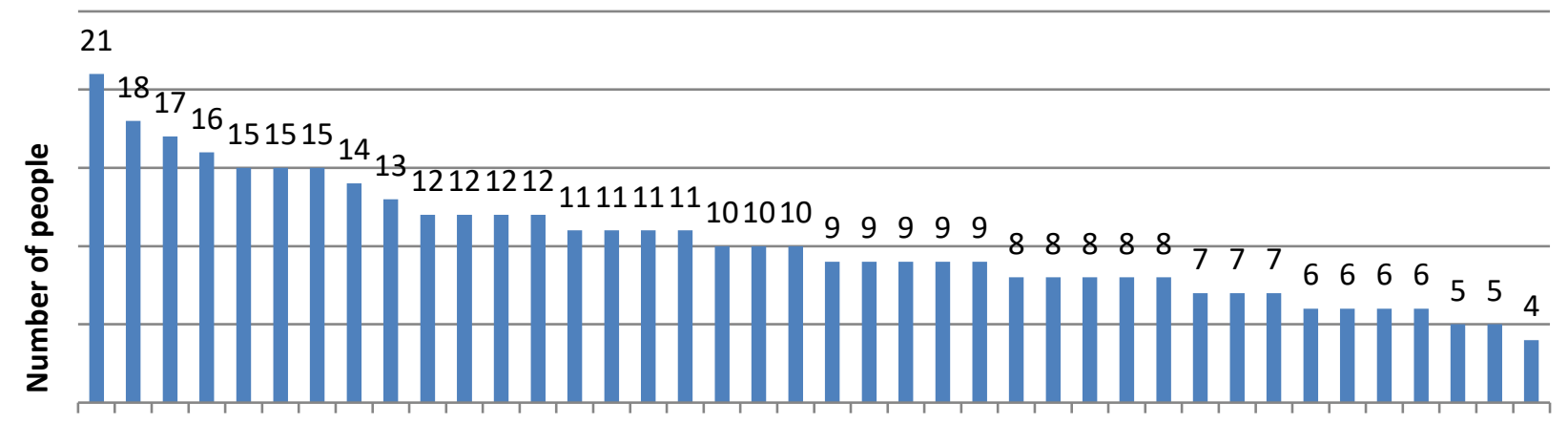

12345678910111213141516171819202122232425262728293031323334353637383940

Values

1 - sacrifice; 2 - wealth; 3 - marriage for love; 4 - respect for traditions; 5 - power; 6 - stability; 7 - popularity; 8 family safety; 9 - duty; 10 - pleasure; 11 - equality; 12 - career; 13 - respect for elders; 14 - a life full of experiences; 15 - love; 16 - work; 17 - creativity; 18 - world peace; 19 - friendship; 20 - professionalism; 21 - self-respect; 22 respect for the opinions of others; 23 - self-discipline; 24 - legality; 25 - personal safety; 26 - politeness; 27 - homeland; 28 - good; 29 - national security; 30 - religion; 31 - inner harmony; 32 - family; 33 - the meaning of life; 34 - spiritual life; 35 - education; 36 - patriotism; 37 - respect for parents; 38 - health; 39 - life; 40 - freedom. 
Figure 13. Distribution of answers by indicator (3 - not very important values)

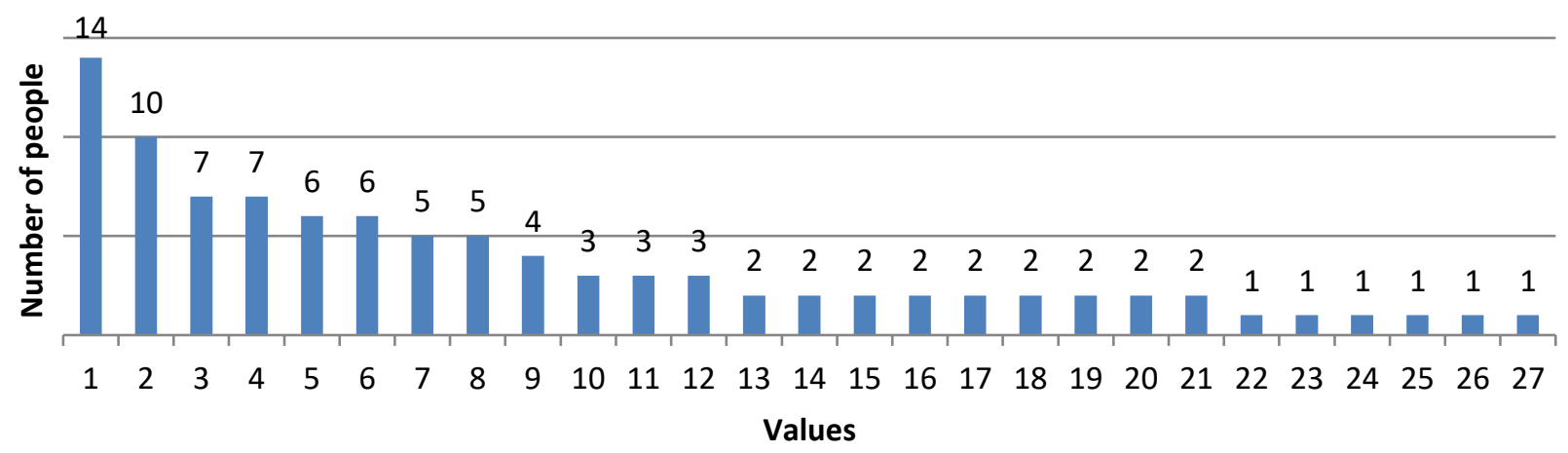

1 - popularity; 2 - religion; 3 - sacrifice; 4 - marriage for love; 5 - wealth; 6 -stability; 7 -respect for traditions; 8 - the meaning of life; 9 - power; 10 - self-respect; 11 - love; 12 - duty; 13 - pleasure; 14 - a life full of experiences; 15 good; 16 - respect for the opinions of others; 17 - self-discipline; 18 - career; 19 - work; 20 - respect for elders; 21 creativity; 22 - world peace; 23 - equality; 24 - inner harmony; 25 - friendship; 26 - health; 27 - legality.

Figure 14. Distribution of answers by indicator (2 - values of little importance)

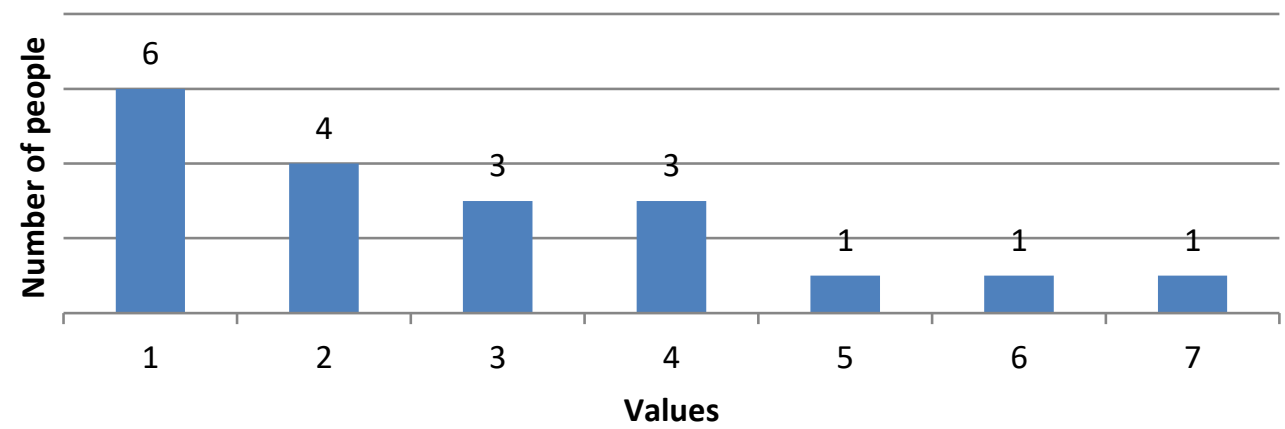

1 - religion; 2 -sacrifice; 3 - power; 4 - popularity; 5 -a life full of experiences; 6 -career; 7 -duty.

Figure 15. Distribution of answers by indicator (1 - not important values)

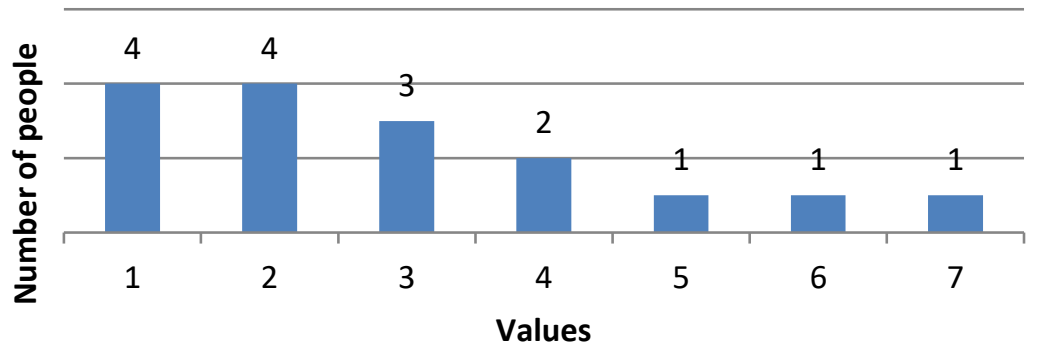

1 - stability; 2 - religion; 3 - popularity; 4 - power; 5 - wealth; 6 - creativity; 7 - marriage for love. 
Figure 16. Distribution of answers by indicator ( 0 - completely indifferent values)

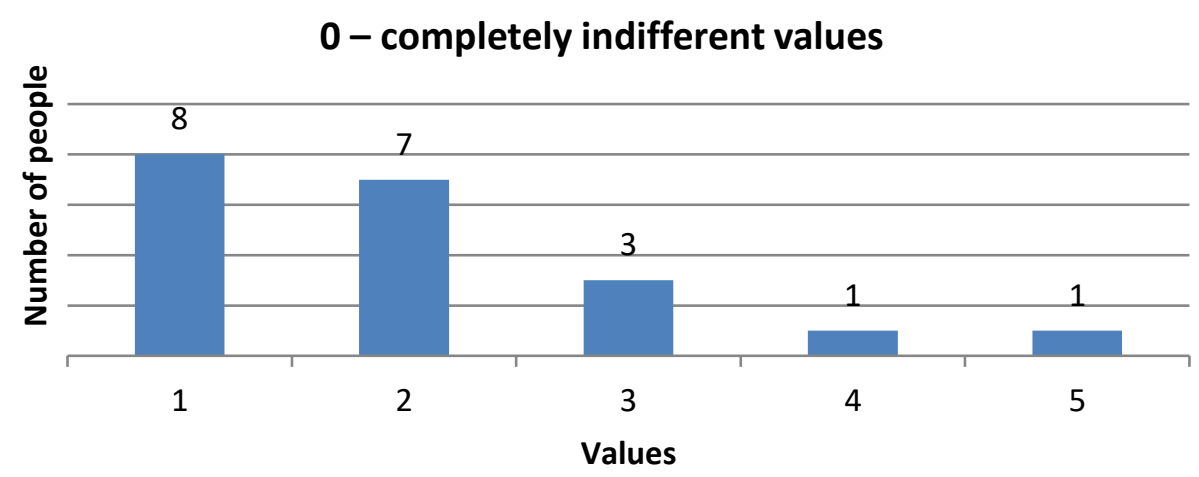

1 - religion; 2 - power; 3 - duty; 4 - creativity; 5 - popularity.

Therefore, Chinese students' top 10 leading (basic) values that were rated six or seven include:

Table 2. Chinese students' top 10 leading (basic) values

\begin{tabular}{ccccc}
\hline № & Value & Rated 7 & Rated 6 & Number of people \\
\hline 1 & National security & 17 & 19 & 36 \\
2 & Health & 22 & 14 & 36 \\
3 & Homeland & 17 & 18 & 35 \\
4 & Family & 17 & 17 & 34 \\
5 & Patriotism & 14 & 18 & 32 \\
6 & Life & 18 & 13 & 31 \\
7 & Freedom & 15 & 15 & 30 \\
8 & Legality & 8 & 21 & 29 \\
9 & Respect for parents & 11 & 18 & 29 \\
10 & Personal safety & 11 & 18 & 29 \\
\hline
\end{tabular}

Below we provide the description of the essence of these values as understood by Chinese students (unedited for spelling or grammar):

1. National security: to defend the homeland; interests of the state; the integrity and stability of the nation; a guarantee of the life of the people; the basis of the country's stability; safety of the people and the country; peace of the nation; the absence of enemy.

2. Health: to have a healthy body; the most important thing; well-being; healthy body; the most valuable gift; the basis of everything; the most important wealth; no illness, wounds; no serious illness; body in good condition; the foundation of everything; this is the main value of life.

3. Homeland: is the mother; home; our home and our mother; our china; to where the soul is pulled; where were you born; big family; the place where I was born and grew up; fatherland; my root; home country, place of birth and growth; where I was born and raised; my root, my support.

4. Family: happiness, love and luck; spiritual pleasure; teach us to love, understand and care; spiritual support; block of close people; parents; strong support and protection; source of personal happiness; close people in the world; dad, mom, brother; me and those closest to me.

5. Patriotism: love for the homeland; love for the fatherland; In the heart and in the blood; contribute to the development of the homeland; ardent love for one's homeland; protect the interests of the country; love for their country, devotion to their people. 
6. Life: study and work to become the best; must be appreciated; Each one is different, but all are precious; the most precious thing for a person; to live well; to be alive; a miracle; the basis of everything; happiness, pleasure and love.

7. Freedom: I have the freedom to choose; have always strived; I can do what I want; the most important thing in my life; choose life according to your soul and your will; will; human right; myself; freedom in thought of speech; be yourself; lack of addictions; independence; to do what you want.

8. Legality: live by the rules; follow the rules; do not offend others; compliance with the law; conform to the right; social guarantee; requirement for all citizens; maintain stability.

9. Respect for parents: respect and love parents; basic human relationships; happy responsibility; thanksgiving; love and understanding; understand them; support for parents and their thoughts; love your parents; gratitude for everything they have done for me; do not argue with parents; respect for parents, love for parents; duty of children; submission and gratitude.

10. Personal safety: know how to protect yourself; human safety; health, physical and psychological; protect yourself; be healthy and complete; safety of life; life guarantee; my life; without security threats.

\section{Vietnamese students' basic values}

The survey was taken by 18 young women and 12 young men aged $19-22$. The results of the survey are presented in diagrams; numbers indicate the number of people who chose this value.

Figure 17. Distribution of answers by indicator (7 - supremely important values)

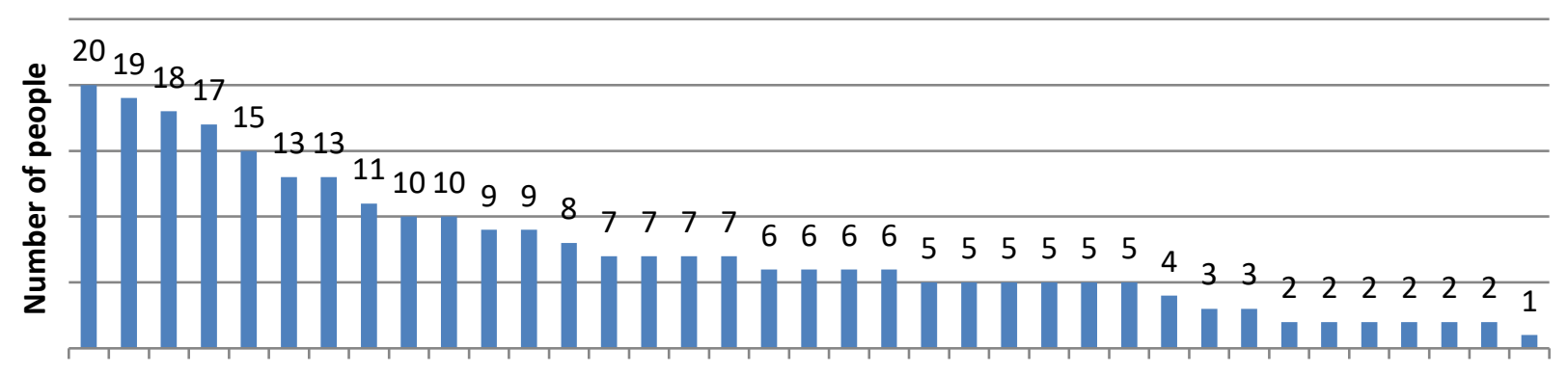

$1223445667 \quad 8 \quad 910111213141516171819202122232425262728293031323334353637$

Values

1 - family; 2 - health; 3 - respect for parents; 4 - family safety; 5 - world peace; 6 - homeland: 7 - life; 8 - patriotism; 9 - freedom; 10 - respect for elders; 11 - the meaning of life; 12 - personal safety; 13 - national security; 14 - spiritual life; 15 - self-discipline; 16 - education; 17 - marriage for love; 18 - politeness; 19 - good; 20 - equality; 21 - creativity; 22 - pleasure; 23 - self-respect; 24 - respect for the opinions of others; 25 - love; 26 - work; 27 - legality; 28 - a life full of experiences; 29 - career; 30 - professionalism; 31 - wealth; 32 - respect for traditions; 33 - inner harmony; 34 friendship; 35 - duty; 36 - religion; 37 - sacrifice. 
Figure 18. Distribution of answers by indicator ( 6 - very important values)

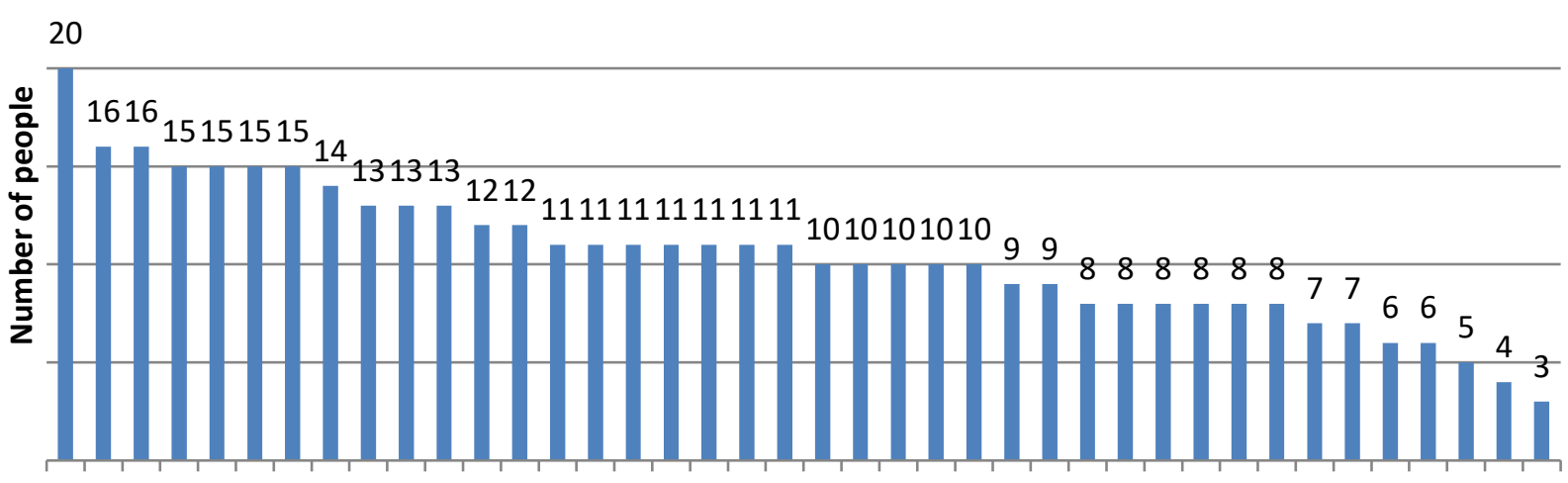

12345678910111213141516171819202122232425262728293031323334353637383940

Values

1 - career; 2 - education; 3 - legality; 4 - politeness; 5 - national security; 6 - equality; 7 - work; 8 - stability; 9 freedom; 10 - good; 11 - friendship; 12 - respect for elders; 13 - personal safety; 14 - respect for traditions; 15 homeland; 16 - love; 17 - health; 18 - professionalism; 19 - patriotism; 20 - power; 21 - spiritual life; 22 - pleasure; 23 - wealth; 24 - self-respect; 25 - respect for parents; 26 - a life full of experiences; 27 - family; 28 - sacrifice; 29 respect for the opinions of others; 30 - world peace; 31 - life; 32 - the meaning of life; 33 - marriage for love; 34 -inner harmony; 35 - self-discipline; 36 - family safety; 37 - creativity; 38 - duty; 39 - popularity; 40 - religion.

Figure 19. Distribution of answers by indicator (5 - quite important values)

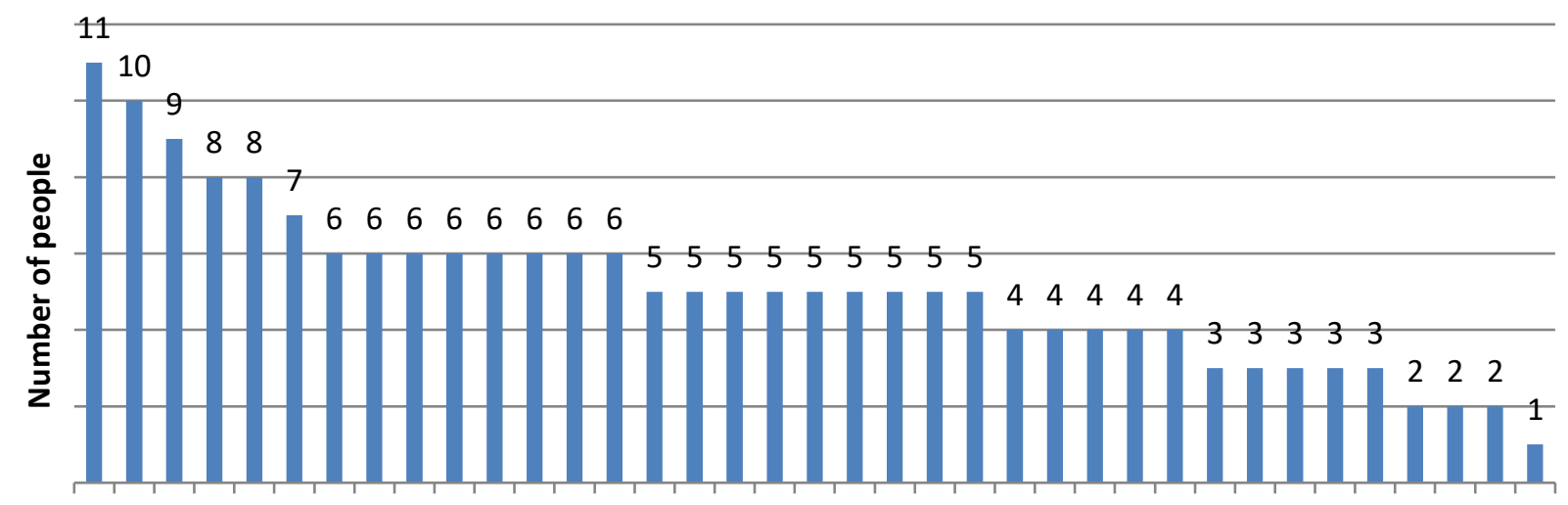

$1223455678 \quad 9 \quad 10111213141516171819202122232425262728293031323334353637$

Values

1 - sacrifice; 2 - inner harmony; 3 - respect for traditions; 4 - professionalism; 5 - the meaning of life; 6 - friendship; 7 - freedom; 8 - spiritual life; 9 -good; 10 - self-discipline; 11 - power; 12 - personal safety; 13 - creativity; 14 - religion; 15 - politeness; 16 - homeland; 17 - self-respect; 18 - respect for the opinions of others; 19 - life; 20 - stability; 21 popularity; 22 - marriage for love; 23 - duty; 24 - pleasure; 25 - a life full of experiences; 26 - national security; 27 love; 28 - work; 29 - wealth; 30 - world peace; 31 - education; 32 - respect for elders; 33 - family safety; 34 - career; 35 - patriotism; 36 - legality; 37 - equality. 
Figure 20. Distribution of answers by indicator (4 - important values)

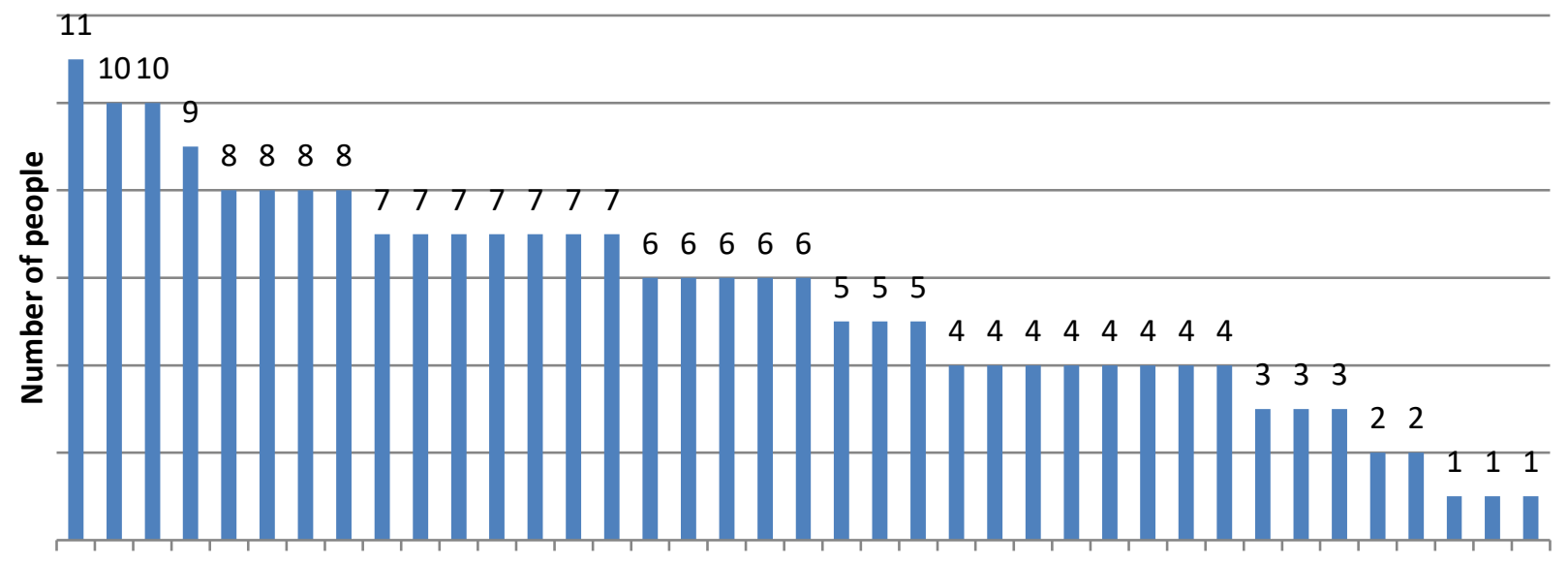

12344567789101112131415161718192021222324252627282930313233343536373839

Values

1 - pleasure; 2 - self-respect; 3 - respect for the opinions of others; 4 - power; 5 - a life full of experiences; 6 - selfdiscipline; 7 - love; 8 - duty; 9 - respect for traditions; 10 - inner harmony; 11 - friendship; 12 - professionalism; 13 legality; 14 - stability; 15 - religion; 16 - spiritual life; 17 - patriotism; 18 - creativity; 19 - popularity; 20 - marriage for love; 21 - wealth; 22 -good; 23 - work; 24 - politeness; 25 - sacrifice; 26 - equality; 27 -life; 28 - career; 29 - education; 30 - the meaning of life; 31 - respect for elders; 32 - national security; 33 - world peace; 34 - personal safety; 35 respect for parents; 36 - family safety; 37 - freedom; 38 - homeland; 39 - family.

Figure 21. Distribution of answers by indicator (3 - not very important values)

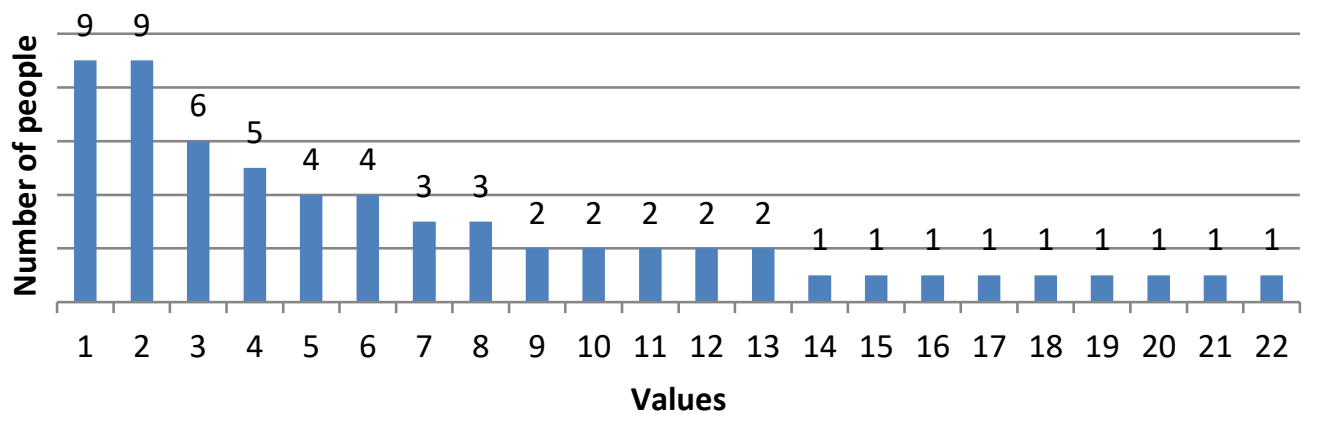

1 - popularity; 2 - religion; 3 - duty; 4 - creativity; 5 - sacrifice; 6 - inner harmony; 7 - a life full of experiences; 8 stability; 9 - respect for the opinions of others; 10 - equality; 11 - power; 12 - security seven; 13 - marriage for love; 14 - spiritual life; 15 - wealth; 16 - world peace; 17 - friendship; 18 - career; 19 - professionalism; 20 - work; 21 - the meaning of life; 22 - respect for elders.

Figure 22. Distribution of answers by indicator (2 - values of little importance)

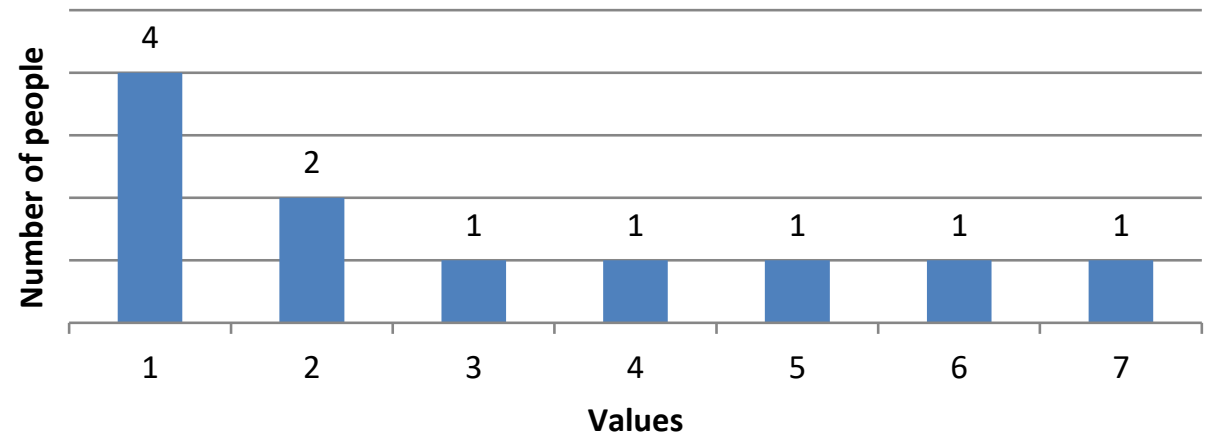

1 - popularity; 2 - power; 3 - a life full of experiences; 4 - sacrifice; 5 - equality; 6 - love; 7 - duty. 
Figure 23. Distribution of answers by indicator (1 - not important values)

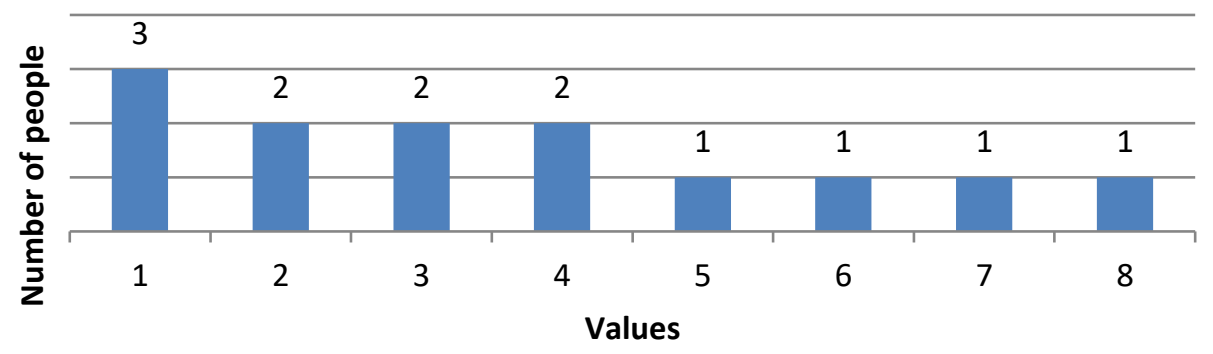

1 - religion; 2 - self-discipline; 3 - marriage for love; 4 - duty; 5 -love; 6 - stability; 7 - creativity; 8 - popularity.

Figure 24. Distribution of answers by indicator ( 0 - completely indifferent values)

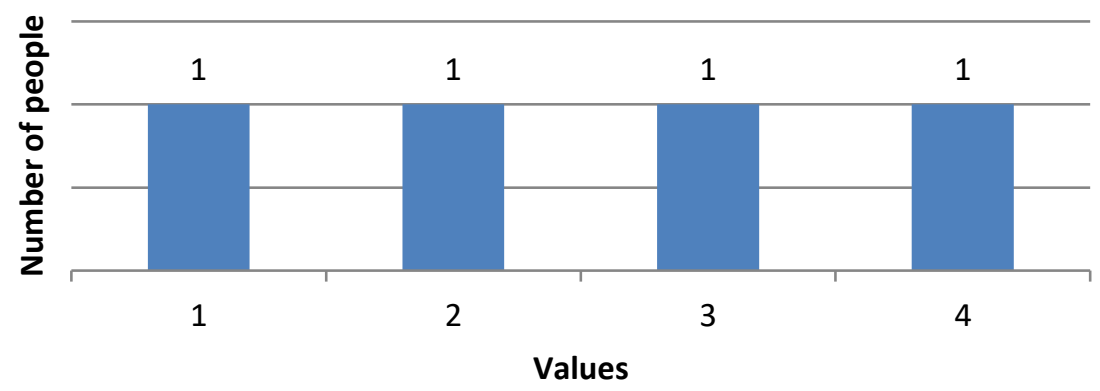

1 - a life full of experiences; 2 - respect for traditions; 3 - equality; 4 - popularity.

Therefore, Vietnamese students' top 10 leading (basic) values that were rated six or seven include:

Table 3. Vietnamese students' top 10 leading (basic) values

\begin{tabular}{ccccc}
\hline № & Value & Rated 7 & Rated 6 & Number of people \\
\hline 1 & Health & 19 & 11 & 30 \\
2 & Family & 20 & 9 & 29 \\
3 & Respect for parents & 18 & 10 & 28 \\
4 & Homeland & 13 & 11 & 24 \\
5 & Freedom & 10 & 13 & 23 \\
6 & National security & 8 & 15 & 23 \\
7 & World peace & 15 & 8 & 23 \\
8 & Career & 3 & 20 & 23 \\
9 & Education & 7 & 16 & 23 \\
10 & Family safety & 17 & 6 & 23 \\
\hline
\end{tabular}

Below we provide the description of the essence of these values as understood by Vietnamese students (unedited for spelling or grammar):

1. Health: no disease; health is the most valuable human property; we can do everything if we are in good health; health is everything; that is everything, if you have health you can do everything.

2. Family: these are not just relatives living nearby. These are close people who are united by feelings, interests, ideals, attitude to life; without it, a person becomes lonely, cut off from society. 
Everyone wants close and beloved people to wait for him at home, assist and give a sense of support; relatives; relatives; family is very important in life.

3. Respect for parents: love and respect for parents, without any doubt, is a sacred feeling; children's respect for parents and elders is the most important of the seven virtues; responsible, filial to parents; just listen and share with your parents whenever you can; we must treat our parents well; love and take care of parents.

4. Homeland: this is the place where we were born and raised; our country; it is the root of a person; this is the place where I was born; by blood; homeland is the home country where you were born and where your family and close friends are.

5. Freedom: it does not depend on another person; freedom means being able to do whatever we want within the law; we can do what we want; do what you like without being banned; "freedom" is when you can do what you love.

6. National security: the state of protection of the state from internal and external threats; security of the country; keep the order of safety for the country itself from the bad; this is a country where we can find peace; this means that there is no crime in our country.

7. World peace: the ideal of freedom, peace and happiness between countries, within all countries, between all people; peace for all, not war; no war; it is the peace of all people in every nation; we can feel calm all over the world; there is no war, countries help each other; there is no war in the world.

8. Career: this is a profession to make money; success, making a lot of money; it is a whole career development to build skills over a long time; good job, a lot of money.

9. Education: learning is always useful; process and result of understanding of systematized knowledge, abilities and skills; it is the knowledge gained through training; education creates people; learn more about all areas of life.

10. Family safety: one of the most important tasks for parents; the apartment must be an impregnable fortress; prevent bad ones; it is a happy family, financially independent and loving each other; we always feel safe when we are with our family; there is no domestic violence; in a family, all members live in harmony.

The survey made it possible to identify the similarities and differences in the value orientations of students from different nationalities (Russian, Chinese and Vietnamese):

Table 4. Basic values of Russian and Chinese students.

\begin{tabular}{ccc}
\hline № & Russia & China \\
\hline 1 & Love & National security \\
2 & Freedom & Health \\
3 & Friendship & Homeland \\
4 & Family safety & Family \\
5 & Life & Patriotism \\
6 & Family & Life \\
7 & Inner harmony & Freedom \\
8 & Good & Legality \\
9 & Marriage for love & Respect for parents \\
10 & World peace & Personal safety \\
\hline
\end{tabular}

Table 5. Basic values of Russian and Vietnamese students.

\begin{tabular}{ccc}
\hline № & Russia & Vietnam \\
\hline 1 & Love & Health \\
2 & Freedom & Family \\
\hline
\end{tabular}




\begin{tabular}{ccc}
\hline 3 & Friendship & Respect for parents \\
4 & Family safety & Homeland \\
5 & Life & Freedom \\
6 & Family & National security \\
7 & Inner harmony & World peace \\
8 & Good & Career \\
9 & Marriage for love & Education \\
10 & World peace & Family safety \\
\hline
\end{tabular}

Table 6. Basic values of Chinese and Vietnamese students.

\begin{tabular}{ccc}
\hline № & China & Vietnam \\
\hline 1 & National security & Health \\
2 & Health & Family \\
3 & Homeland & Respect for parents \\
4 & Family & Homeland \\
5 & Patriotism & Freedom \\
6 & Life & National security \\
7 & Freedom & World peace \\
8 & Legality & Career \\
9 & Respect for parents & Education \\
10 & Personal safety & Family safety \\
\hline
\end{tabular}

\section{CONCLUSION}

As a result of the survey, we identified basic values of Russian and foreign (Chinese and Vietnamese) students, as well as similarities ("overlapping areas" - These areas are set in bold in the tables) and differences in their value orientations.

Common basic values for Russian and Chinese students are "freedom", "life" and "family", for Russian and Vietnamese students - "freedom", "family safety", "family" and "world peace", for Chinese and Vietnamese students - "freedom", "national security", "health", "homeland", "family" and "respect for parents". However, one should pay attention to the fact that these values hold different positions in the hierarchy of basic values. Thus, among the Russian respondents, "freedom" is in second place and in seventh among the Chinese; "family" ranks sixth in the value orientations of Russians and fourth for the Chinese. The value "life" for both the Russians and the Chinese ranks fifth and sixth (approximately the same result). The rest of the values of the representatives of these two nationalities do not coincide at all. The degree of importance of values within the same culture also changes. The traditional Chinese culture value "family" is no longer ranked first in the hierarchy of values among today's youth. The emphasis is shifting towards "national security", "health" and "homeland".

In the lists of values of Russian and Vietnamese students, there are more "overlapping areas", although the coinciding values occupy different lines in the hierarchy. "Freedom", which is in second place among Russian students, is in fifth place among Vietnamese. "Family safety" is in fourth place for Russian respondents and tenth for Vietnamese. Family plays a more important role for the Vietnamese than for the Russians (second place compared to sixth for the Russians). "World peace" is ranked seventh for Vietnamese audiences, while tenth for Russians, however, for Russian students, this basic value is closely intertwined with the others: "love", "freedom", "friendship", "life", "family safety", "good", "inner harmony". It should be noted that "education" was included in the list of basic values among the Vietnamese, while for the Russians this value did not receive 
seven or six points. This may be since Russian freshmen and sophomore students who entered universities after leaving school, do not yet realize the prospects that education gives them due to their age. Vietnamese students come to study in Russia, and for them, this is a serious, deliberate decision that requires a conscious approach. One can assume that for the Vietnamese students, the prospect of obtaining a higher education is already clear: a diploma from a Russian university makes it possible to get a good job at home. The value of "Health" is a priority for Vietnamese students: a healthy person can work hard and earn good money, provide for a family, the value of which is confirmed by the second place in the hierarchy.

In the list of basic values of Chinese and Vietnamese students, six out of ten values coincide. However, we should note that for Chinese students "national security" comes first, while for Vietnamese students it is in sixth place. The value of "health" is a priority for representatives of both cultures: second place in Chinese and first in Vietnamese. The value of "homeland" is important for the representatives of these nationalities. It ranks third among the Chinese ("national security" ranks first), while among the Vietnamese it is fourth. For students from Vietnam, traditionally the main concept is the family. For them, the Homeland is a big family. Vietnamese students put this value in second place, and Chinese students in fourth (the emphasis is shifted in favor of "homeland"). The values "freedom" and "respect for parents" are among the ten basic values but these values also occupy different places in the hierarchy: in the Vietnamese audience, their significance is higher.

This research makes a certain contribution to the further study of values, both in the culturallinguistic and linguodidactic aspects. The practical significance of the study is expressed in the possibility of using the results obtained when writing nationally oriented textbooks and study guides on Russian as a foreign language (RFL), as well as for developing an improved nationally oriented system of exercises. On the one hand, one must consider the value orientations of foreign students in the RFL lessons, and, on the other hand, acquaint them with the basic values of Russian students. This will help to avoid problems in the process of interpersonal communication, ways of the students' adaptation in another country. In the process of teaching RFL, one can offer foreign students texts for reading and dialogues that reflect the "overlapping areas" of their basic values with the values of Russian students. This helps to increase the motivation of foreign students to learn the Russian language, makes the learning process more interesting and efficient. In addition, the results of the research can be used when providing courses on cultural linguistics, axiological linguistics, sociolinguistics, in the theory and practice of intercultural communication.

The period of youth is the period of personality formation and transition from intermediate statuses (schoolchild, student) to permanent statuses (professional, family, etc.). The "image of the near future" depends on how competent the state youth policy will be (Pikuleva, 2015, p. 30). Youth as an integral part of any society is a kind of indicator of the ongoing changes. In this regard, the value priorities of modern students require further study.

Authors' Contributions: Tatiana Vyacheslavovna Nesterova: conception and design, acquisition of data, analysis and interpretation of data, drafting the article, critical review of important intellectual content. Svetlana Georgievna Persiyanova: conception and design, acquisition of data, analysis and interpretation of data, drafting the article, critical review of important intellectual content. Bagaudin Ibragimovich Karadzhev : conception and design, acquisition of data, analysis and interpretation of data, drafting the article, critical review of important intellectual content. All authors have read and approved the final version of the manuscript.

Ethics Approval: Not applicable.

Acknowledgments: We would like to thank the graduate student of the Pushkin State Russian Language L.A. Zaitseva for taking an active part in surveying and processing the results. 


\section{REFERENCES}

Abushenko, V.L. (2002). Aksiologiya. Vsemirnaya entsiklopediya: Filosofiya KhKh vek [Axiology.World Encyclopedia: Philosophy of the 20th century]. Moscow: AST.

Araujo, A., \& Silva, I. P. (2020). Maker culture and educational robotics in physics teaching: developing an automated traffic light in high school. Journal of Research and Knowledge Spreading, 1(1), e11654.

Durkheim, É. (1995). Tsennostnye i "realnye" suzhdeniya. Sotsiologiya: Ee predmet, metod, prednaznachenie [Value Judgments and Judgments of Reality. Sociology, its subject, method and purpose]. Moscow: Kanon.

Glazkova, I.G. (2009). Tsennostnye osnovaniya obraza zhizni sovremennogo rossiiskogo i amerikanskogo studenchestva [Value justifications for the way of life of Russian and American students]: Dissertation ... the Candidate of Sociological Sciences. Ekaterinburg.

Ishankulova, D.G. (2011). Kommunikativnye tsennosti v leksiko-frazeologicheskoi sisteme angliiskogo yazyka [Communicative values in English Lexis and Phraselogy]: Dissertation ... the Candidate of Philological Sciences. Moscow.

Ivin, A.A. (2019). Aksiologiya: uchebnik dlya akademicheskogo bakalavriata [Axiology: a textbook for an academic undergraduate program]. Moscow: Yurait. Retrieved from: https://iphras.ru/uplfile/root/biblio/pj/pj_4/6.pdf

Karasik, V.I. (2002). Yazykovoi krug: lichnost, kontsepty, diskurs [Language circle: personality, concepts, discourse]. Volgograd: Peremena.

Karasik, V.I. (2014). Aksiogennaya situatsiya kak edinitsa tsennostnoi kartiny mira [Axiogenic situation as an evaluative world mapping unit]. Politicheskaya lingvistika [Political linguistics], 1(47), 65-75.

Karasik, V.I. (2015). Lingvokulturnye tsennosti v diskurse [Linguistic and cultural values in discourse]. Inostrannye yazyki v vysshei shkole, 1(32), 25-35.

Karasik, V.I. (2015). Yazykovaya spiral: tsennosti, znaki, motivy [Language Spiral: Values, Signs, Motives]: Monograph. Volgograd: Paradigma.

Karasik, V.I. (2018). Tsennosti kak kulturno znachimye orientiry povedeniya [Values as culturally significant behavioral benchmarks] Lingvokulturnye tsennosti v yazykovom soznanii i kommunikativnoi praktike [Linguocultural values in linguistic consciousness and communicative practice]: proceedings of the International scientific conference. Tianjin.

Karasik, V.I. (2019). Yazykovye mosty ponimaniya [Language bridges of understanding]. Volgograd: PrinTerra-Dizain.

Kratkaya filosofskaya entsiklopediya [Brief philosophical encyclopedia] (1994). Moscow: Progress.

Kryukov, V.V. (2003). Osnovnye kontseptsii teorii tsennostei [Main concepts of the value theory]. Novosibirsk: Novosib. gos. tekhn. un-t.

Lapin, N.I., Belyaeva, L.A. (1996). Dinamika tsennostei naseleniya reformiruemoi Rossii [The trend of values for the population of Russia under reform]. Moscow: Editorial URSS.

Magun, B.C. (2002). Struktura i dinamika trudovykh tsennostei rossiiskogo naseleniya (po dannym mezhdunarodnykh issledovanii 1990-kh gg.) [Structure and trend of work-related values of Russian population (based on international studies in the 1990s]. Moscow: Rossiya reformiruyushchayasya.

Magun, V.S., Rudnev, M.G. (2008). Bazovye tsennosti rossiyan i drugikh evropeitsev (po materialam oprosov 2008 goda) [Basic values of Russians and other Europeans (based on 2008 surveys)] Retrieved from: http://www.civisbook.ru/files/File/Magun_Rudnev_Bazovye.pdf .

Mitryushin, S.A. (2008). Zhiznennye tseli studencheskoi molodezhi kak regulyator sotsialnogo povedeniya [Life goals of student youth as social behavioral regulator]: Dissertation ... the Candidate of Sociological Sciences. Moscow.

Nesterova, T.V., Nagorneva, A.A. (2016). Sotsiokulturnyi portret sovremennogo studenta [Sociocultural portrait of the modern student]. Mezhdunarodnyi aspirantskii vestnik [International post-graduate bulletin], 2, 14-18.

Oliveira, A. M., Gerevini, A. M., \& Strohschoen, A. A. G. (2017). Diário de bordo: uma ferramenta metodológica para o desenvolvimento da alfabetização científica. Revista Tempos e Espaços em Educação, 10(22), 119-132.

Parsons, T. (1972). Amerikanskaya sotsiologiya [American sociology] Perspektivy, problemy, metody [Prospects, problems, methods]. Moscow: Progress.

Pikuleva, Yu.B. (2015). Obraz blizhaishego budushchego: o nekotorykh statisticheskikh rezultatakh provedennogo anketirovaniya studentov [The image of the nearest future: on statistical results of the survey of students] 
Natsionalnye tsennosti v yazyke i kommunikatsii [National values in language and communication]: Abstracts of reports for the scientific seminar with international participation. Ekaterinburg: Azhur.

Prokhorov, A.M. (2002). Bolshoi entsiklopedicheskii slovar [Large Encyclopedic Dictionary]. (2002). Saint Petersburg: Norint. Retrieved from: https://slovar.cc/enc/bolshoy/2130772.html

Rodrigues, B. M., Santos, J. E. B., \& Vasconcelos, C. A. (2020). Conceptions of undergraduate students in Chemistry on the use of interactive interfaces in and for the activities developed in the distance course. Journal of Research and Knowledge Spreading, 1(1), e11649.

Rokeach, M. (1973). The nature of Human Values. New York: Free Press.

Rozenova, M.I. (2006). Tsennost lyubvi v predstavleniyakh sovremennykh studentov [The value of love in the beliefs of modern students]. Vysshee obrazovanie v Rossii, 6, 38-47.

Rudnev, M.G. (2009). Bazovye tsennosti naseleniya: sravnenie rossiyan s zhitelyami drugikh evropeiskikh stran [Basic values of population: comparing Russians and citizens of other European countries]: Dissertation ... the Candidate of Sociological Sciences. Moscow.

Santos, J. E. B. (2020). Cartographic narratives: the teaching of mathematics and ICT. Journal of Research and Knowledge Spreading, 1(1), e11645.

Schwartz, S.H. (1992). Universals in the contentand structure of values: Theory and empirical tests in 20 countries, in: M. Zanna (ed.). Advances in experimental social psychology. New York: Academic Press.

Schwartz, S.H., Bilsky, W. (1958). Toward a theory of the universal content and structure of values: Extensions and cross-cultural replications. Journal of Personality and Social Psychology, 58(5), 878-891.

Schwartz, S.H., Bilsky, W. (1987). Towards a psychological structure of human values. Journal of Personality \& Social Psychology, 53(3), 550-562.

Sinyachkin, V.P. (2011). Obshchechelovecheskie tsennosti v russkoi kulture: lingvokulturologicheskii analiz [Universal human values in Russian culture: a cultural linguistic analysis]: Dissertation ... the Doctor of Philological Sciences. Moscow.

Silva, C. V. S., \& Santos, G. O. (2020). Digital interfaces: a methodological proposal as a strategy of teaching and learning in Mathematics classes. Journal of Research and Knowledge Spreading, 1(1), e11651.

Svetonosova, T.A. (2006). Sopostavitelnoe issledovanie tsennostei v rossiiskom i amerikanskom politicheskom diskurse [Comparative study of values in Russian and American political discourse]: Dissertation ... the Candidate of Philological Sciences. Ekaterinburg.

Thamas, W. (1976). Cholp poliskiw Europe I Ameryce. Warszawa: Lud. Spold. Wyd.

Tsennostnye orientatsii rossiiskoi molodezhi i realizatsiya gosudarstvennoi molodezhnoi politiki: rezultaty issledovaniya [Value orientations of Russian youth and the implementation of state youth policy: study results]: a monograph. (n.d.). Moscow: Izdatelskii dom GUU.

Tsennostnyi oprosnik Shvartsa [S. Schwartz Value Survey]. (n.d.). Retrieved from: https://hrportal.ru/tool/cennostnyy-oprosnik-shvarca

Tseplyaev, A.N. (2000). Sotsialnye tsennosti sovremennoi rossiiskoi molodezhi: sostoyanie, dinamika, napravlennost [Social values of modern Russian youth: status, trend, orientation]: Dissertation ... the Candidate of Philosophical Sciences). Moscow. 192 p.

Vagin, D.Yu. (2015). Preemstvennost pokolenii v sfere dukhovno-nravstvennykh tsennostei sovremennoi molodezhi Rossii [Intergenerational continuity in spiritual and moral values of modern Russian youth]: Dissertation ... the Candidate of Sociological Sciences. Nizhnii Novgorod.

Votintseva, E.V. (2018). Sposoby yazykovoi reprezentatsii tsennostnykh orientirov v yazykovoi kartine mira molodezhi [Methods of linguistic representation of values in the linguistic worldview of young people]: Dissertation ... the Candidate of Philological Sciences. Ufa.

World Values Survey 1981-2014 Longitudinal Aggregate. (n.d.). World Values Survey Association. Retrieved from: http://www.worldvaluessurvey.org/WVSContents.jsp?CMSID=intinfo

Zemrakh, T.V. (2005). Bazovye tsennosti sovremennoi molodezhnoi kultury [Basic values of the modern youth culture]: Dissertation ... by the Candidate of Philosophical Sciences. Rostov-on-Don. 
Received: 11 January 2021 | Accepted: 12 February 2021 | Published: 21 February 2021

(c) (1)

This is an Open Access article distributed under the terms of the Creative Commons Attribution License, which permits unrestricted use, distribution, and reproduction in any medium, provided the original work is properly cited. 